\title{
Designing Landscapes for Child Health
}

\author{
Aydın Özdemir
}

Additional information is available at the end of the chapter

http://dx.doi.org/10.5772/55762

\section{Introduction}

Childhood obesity has reached epidemic proportions and is a major public health problem globally (Ebbeling et al., 2002; Pate et al., 2008), which causes many serious health-related problems (van Emmerik et al., 2012; Daniels et al., 2005; Din-Dzietham et al., 2007; Lorch and Sharkey, 2007) such as coronary heart disease, diabetes, osteoporosis (Sallis and Owen 1999; Pate et al. 1995; Hume et al. 2005; Raitakari et al., 1997; Teixeira et al., 2001; Bailey, 1995; Berenson, 1986; Van Mechelen et al., 2000), sleep apnea syndrome (Wabitsch, 2000) and psychological problems (Dietz, 1998; Daniels, 2006). Obesity is caused by a higher energy intake than energy expenditure, resulting in excessive weight gain (Koezuka et al., 2006). Theory implies that energy balance is maintained by energy expenditure, and physical activity helps to improve energy expenditure resulting weight loss (Weinsier et al., 1998; Lambert and Goedecke, 2004; Chaput et al., 2011). Physical activity helps to improve metabolic profile, muscular and bone health (Anderson and Butcher, 2006; Ekelund et al., 2008; Hind and Burrows, 2007; Biddle et al., 1998), mental health and academic performance (Singh et al., 2012; Strong et al., 2005). For a healthy living, it is recommended that children should participate to at least $60 \mathrm{~min} /$ day of physical activity and include vigorous physical activity at least 3 days/week (Strong et al., 2008). Daily walking is a useful activity for healthy living (Shultz et al., 2011) and children should accumulate at least 12.000 steps per day to maintain a healthy weight (Tudor-Locke et al., 2011).

Environmental factors, which discourage energy expenditure and thus limit the availability of facilities for physical activity, have potential to influence body weight and healthy behavior (Lachowycz and Jones, 2011; Feng et al., 2010; Papas et al., 2007; Sallis et al., 2000). Studies reported a positive relationship between access to greenspaces and physical activity (Lachowycz and Jones, 2011; Kaczynski and Henderson, 2007; Kaczynski et al., 2008). Increased vegetation was associated with reduced weight among children (Liu et al., 2007) and neighborhood greenness influenced less weight gain in children (Bell et al., 2008). Promoting physical activity among children, therefore, should be a public health priority, 
and studies should focus on the determinants of the environmental variables of physical activity.

Previous reviews found associations between aesthetic attributes of the physical environment with physical activity (Sallis and Owen, 1999; Sallis et al., 1998; Owen et al., 2000; Humpel et al., 2002). Models developed from such research help to explain environment-behavior relationships that can play a key role in linking research, policy and practice. In this context, there is a need for high-quality empirical evidence supporting environmental influences on health (Humpel et al., 2002) and an understanding of how these environmental attributes are related to promoting more physical activity.

Within the extant literature there are many models and theories which help to conceptualize a potential way of mapping ecological, social and biological frameworks. Ecological model implies that behavior is influenced by the environmental factors, and changes in the environment-positive or negative-will have effects on health (McLeroy et al., 1988). The evidence shows that the built environment-the office environments (Chao et al., 2003), healing environments such as hospitals and day care centers (Whitehouse et al., 2001; Cooper-Marcus and Barnes, 1999), school buildings (Cradock, et al., 2007; Everett Jones et al., 2003), outdoor school environments (Rivkin, 1997; Dyment et al., 2009; Dyment and Bell, 2007; Tranter and Malone, 2004; Brink et al., 2010; Özdemir and Y1lmaz, 2008), housing and home environments (Shaw, 2004; Wigle, 2003; Evans et al., 2003; Saegert, 1982), recreation facilities and access to green spaces (Wells and Evans, 2003; Maller et al., 2006; Stigsdotter et al., 2010; Sugiyama et al., 2008), greening vacant urban space (Branas et al., 2011), the design of neighborhoods (Wells and Yang, 2008) and store locations (Holsten, 2009) - will affect health and well-being of users.

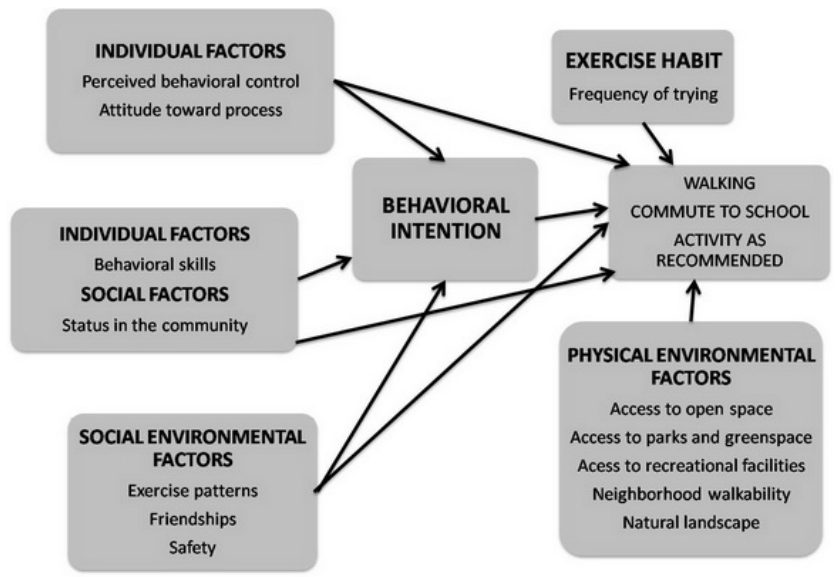

Figure 1. Model of environment health relation (Adapted from Pikora et al., 2003).

Established links between health and environment suggest that individual, social and physical environmental factors are related to behavioral intention, thus, shape our way of activities (Figure 1). As a result, improvements in the physical environment might lead to a number of 
long-term health outcomes: decrease in obesity, increase in physical activity, and decrease in serious health problems. Several studies have linked urban green space to fewer health complaints (Maas et al., 2009; Takano et al., 2002; Mitchell and Popham, 2008; Richardson and Mitchell, 2010; Mitchell et al., 2011). Based on these numerous health outcomes, planning and design decisions should take into consideration these public health impacts.

\subsection{Environmental characteristics and health outcomes}

Research on the determinants of potential environmental variables of physical activity is a growing trend (Carnegie et al., 2002; Sallis et al., 1990; Brug et al., 2005; Humpel et al., 2002; Owen et al., 2004; Trost et al., 2002; Saelens et al., 2003; Cunningham and Michael 2004; Wendel-Vos et al., 2007). Despite extensive research, the determinants of physical activity are not fully understood (Dishman and Sallis, 1994; Sallis and Owen, 1997; Vita and Owen, 1995). In order to promote planned and systematic physical activity among children, the key issue should be to gain insight into environmental factors that facilitate or obstruct physical activity among children (Baranowski and Jago, 2005; Wendel-Vos et al., 2004).

The social model of health conceptualizes health in environmental and social rather than just physical or individual terms (Figure 2). Research on the determinants of healthy child development showed that studies should include a mix of social and environmental factors-income, education, health and everyday environments-and all levels of society (Bonnefoy, et al., 2007). Healthy children will be those who are enabled to satisfy their needs and change, and cope with the urban environment (Davis and Jones, 1996; Black and Krishnakumar, 1998). However there is no systematic analysis of health effects of environments (Davis and Jones, 1996). Physical activity researchers, on the other hand, have not seriously addressed how the wider social and physical environment influences children's play and mobility.

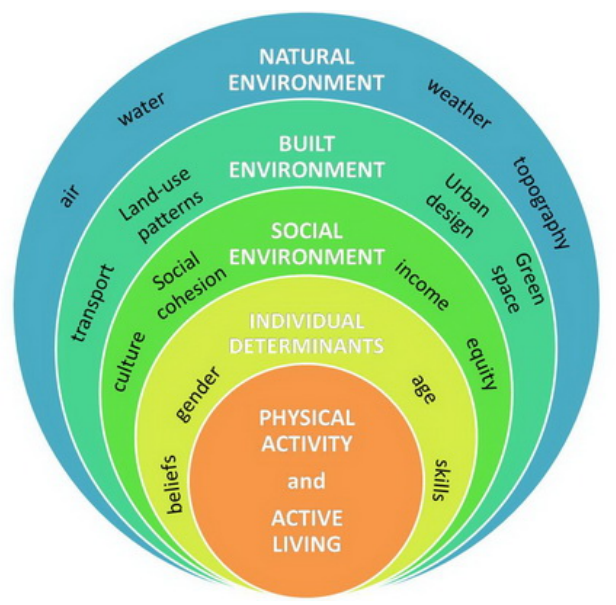

Figure 2. Factors influencing physical activity in communities (Adapted from Dahlgren and Whitehead, 1991). 


\subsection{Outdoor school environments and health outcomes}

Despite the fact that most physical activity by children is undertaken outside of the school building (Sallis et al., 1993; Vicent and Pangrazi, 2002), schools have not been recognized as key settings both to promote and to contribute to physical activity guidelines (Zimring et al., 2005; Zask et al., 2001; Iverson et al., 1985; Biddle et al., 1998) because children spend a large proportion of their time there (Biddle et al., 1998; Iverson et al., 1985).

School environments and policies have been studied for their effects on healthy behavior and obesity prevention (Trudeau and Shepherd, 2005; Story et al., 2006; Wechsler et al., 2000). Additionally, school building and campus characteristics have been associated with objective measures of physical activity (Cradock et al., 2007). Effects of school recess time (Ridgers et al., 2006), type and size of space and fixed outdoor equipments (Sallis et al., 2001), school size and available number of balls (Zask et al., 2001), size of schoolyards (Özdemir and Yılmaz, 2008), the provision of extra equipment (Sallis et al., 2003; Verstraete et al., 2006), school ground paintings (Stratton and Mullan, 2005; Ridgers et al., 2007) and school environment improvements (Haug et al., 2010) have been found to be associated with physical activity. Past studies concentrated on environmental influences on health outcomes, however, found limited and ambiguous results (Ferreira et al., 2007; Davison and Lawson, 2006). Children were found to be healthier in large schoolyards (Özdemir and Yllmaz, 2008); however, children were more active in small schoolyards (Özdemir and Çorakçı, 2010). Additionally, limited outdoor play time and short recess were associated with a higher body mass index levels in young children (Ernst and Pangrazi, 1999; Alhassan et al., 2007; Ridgers et al., 2006).

Access to urban parks and recreational facilities, schoolyard renovations, type and quality of play spaces have been studied for their effects on increased physical activity in children (Sallis et al., 2009; Stucky-Ropp and DiLorenzo, 1993; Sallis et al., 1993). Some studies reported a significant association between active commuting to school and weight status (Faulkner et al., 2009; Lee et al., 2008; Lee and Tudor-Locke, 2005; Heelan et al., 2005; Pabayo et al., 2011; Rosenberg, et al., 2006; Mendoza et al., 2011), and children who actively commute to school are healthier than passive commuters (Heelan et al., 2005; Özdemir and Yilmaz, 2008; Lee and Tudor-Locke, 2005). In a comparison between cycling and non-cycling children, after 6 years of observations, children who cycle to school were found healthier (Cooper et al., 2008).

In order to develop school-based interventions, it is crucial to better understand the ways by which the school environment may promote or inhibit children's physical activity (van Sluijs et al., 2012). For a sustainable and a successful transition of school grounds from a conventional asphalt surface to a natural educational setting, outdoor school environments need to be conducive to health promotion with an integrated and a participatory approach.

\subsection{Neighborhood characteristics and health outcomes}

Active behaviors should be promoted with city planning and infrastructure by creating safe and accessible urban environments (Lopez and Hynes, 2006; Frank et al., 2005; Badland and 
Schofield, 2005; Handy et al., 2002), which in turn enhance energy expenditure. Environmental factors are influential in type and frequency of activity, such as climate of the region, terrains, neighborhood and traffic safety, and parents' perceptions of their children's activities outdoors (Saelens et al., 2003; Leslie et al., 2005). Sociocultural background (Flavia et al., 2010; Fredriks, 2005) and neighborhood characteristics are effective in obesity prevention; children in deprived neighborhoods are more likely to be overweight (deJong et al., 2011; Janssen et al., 2006; Lackshman et al., 2010; Veugelers and Fitzgerald, 2005). Several reviews indicate that people with low income are more likely to live in poor quality built environments, and this contributes to poor health (Lavin et al., 2006; Sallis et al., 2009). Parents in lower income neighborhoods reported the highest rates of unpleasant walking environments (van Lenthe et al., 2005). Neighborhood violent crime may be a significant environmental barrier to outdoor physical activity for urban dwelling (Bennett et al., 2007; Gomez, 2004).

Studies reported a positive relationship between access to greenspaces and physical activity (Kaczynski and Henderson, 2007; Lachowycz and Jones, 2011; Lee and Maheswaran, 2010). Children living in neighborhoods with playgrounds, parks and other recreational facilities engage in more physical activities and are less likely to be obese (Veugelers et al., 2008; Gordon-Larsen et al., 2006). Increased vegetation was associated with reduced weight among children (Liu et al., 2007) and neighborhood greenness influenced less weight gain in children (Kaczynski and Henderson, 2007; Roemmich et al., 2006; Bell et al., 2008). Park playgrounds were influential in reduced BMI values in children (Potwarka et al., 2008). A cross-sectional survey of adults in 8 European cities found that people in the greenest areas are less likely to be obese (Ellaway et al., 2005). Parents complained about the heavy traffic streets and the absence of a park nearby, which limited their children's play outside. Additionally, some parents indicated that their children never play outside of their home, even during the weekend due to the lack of nearby park (Aarts et al., 2012).

\subsection{Measurement techniques of physical activity}

The assessment techniques of physical activity can be grouped into two categories: subjective and objective. Subjective techniques include observations, questionnaires, interviews, physical activity logs and activity diaries. Objective techniques include physiological indices such as heart rate monitoring and electronic motion sensors (accelerometry, pedometer measurements), and tracking movement with Global Positioning Systems (GPS).

\subsubsection{Subjective assessments}

Assessment of children's physical activity levels is a research-priority (Trost et al., 2000) and several tools have been developed for this assessment (Welk, 2002; Ekelund et al., 2001). The most common technique is the subjectively measurement of child physical activity by survey techniques with self-reports (Loprinzi and Cardinal, 2011). Sallis et al. (2002) discussed self-report techniques that are defined as inexpensive and easy to administer. 
However, accuracy and reliability of self-report data are discussed, since young children may have difficulties in recalling their activity behaviors (Pate et al., 1995; Welk et al., 2000; Affuso et al., 2011), which calls for a response bias that affect the quality of data (Klesges et al., 2004).

Some studies included parental reports of their children's height and weight (Hinkley et al., 2008; Oliver et al., 2007; Eiser and Morse, 2001), which are often inaccurate (Rowland, 1990). Indirect subjective measures such as parent and teacher questionnaires were also administered to assess child physical activity (Oliver et al., 2007) and health related quality of life (Eiser et al., 2000).

The evaluation of the children's perception of the environment and its effect on behavior should be provided by multi-method approach. Focus groups are useful techniques in research with children (Hoppe et al., 1995; Morgan et al., 2002; O'Dea, 2003; Vaughn et al., 1996), and discussing topics in groups in schools is an appropriate method to gain insight into child views on several topics. Focus group method has been used for providing data which are deeper, more qualified and appropriate to the purpose of the research. Focus group is one of the rapid scanning methods which provide qualitative information in a short time. It is generally realized with 10-12 participants. The moderator provides the different/same opinion, comment or information to occur via questions which help to discuss. It is one of the most frequently used information gathering methods, because it provides convenience to reach different information in a short time, enables the flexible, unexpected and unknown findings to occur, catches extreme points and is cost-effective (Babbie, 2006; Debus, 1990; Engelbrektsson, 2002; Krueger and King, 1998; Krueger and Casey, 2000).

\subsubsection{Objective measurements}

Direct measures with objective tools such as accelerometers, pedometers, heart-rate monitoring (Oliver et al., 2007; Sirard and Pate, 2001; Trost et al., 2000) and GPS techniques can be used to monitor, measure and assess childhood physical activity. The use of these tools reduces the bias commonly associated with self-report measures. The objective assessment with measurement tools has high practical utility, high reliability and high validity relative to subjective measurements (King et al., 2011; Corder et al., 2008).

\section{Pedometers and accelerometers}

Accelerometer-based devices provide valid and objective information on physical activity with several outputs such as calories and fat burnt during a period of time, time spent in moderate and vigorous activity, distance walked and total step counts (Bassett and John, 2010). They are battery-operated devices that are attached to the wrists or ankles of the subjects to measure the number of steps during activities. Pedometers enable translating physical activity recommendations into pedometer-based step goals and commonly used in research with children (Pate et al., 2010; Mitre et al., 2009; Marshall et al., 2009; Tudor-Locke et al., 2011; Tudor-Locke and Bassett, 2004). They are widely used in medical research to 
compare descriptive data (steps per day) for specific age groups, cultures and environmental contexts (Whitt et al., 2004). However, they fail to capture data of seated activity (Berlin et al., 2006) and they only measure horizontal activities such as walking and running.

Accelerometers are also useful, reliable and valid tools with motion sensors to assess the intensity, frequency, pattern and duration of activity, which is an advantage over the pedometers (Berlin et al., 2006). Data collected by these devices should be processed on a computer. Research that included pedometer measurements found that obese children have lower pedometer counts than non-obese children (Tudor-Locke and Bassett, 2004; Eisenmann et al., 2007; Al-Hazzaa, 2007). Tudor-Locke and Bassett (2004) proposed a system used to classify healthy adults based on their activity levels: $<5,000$ steps a day for sedentary lifestyle, 5,000 to 7,499 steps a day for low activity, 7,500 to 9,999 steps a day for somewhat active, 10,000 to 12,499 steps a day for active, and $>12,500$ steps a day for highly active.

\section{Heart rate monitoring}

Heart rate (HR) monitoring is an objective, inexpensive and unobtrusive assessment tool providing indirect, intensity and duration data of physical activity among children (Loprinzi and Cardinal, 2011). HR monitoring provides information about total energy expenditure and about the amount of time spent in high-intensity activity (Ainslie et al., 2003). This tool has provided a valid and reliable objective estimate of physical activity (Rowlands and Eston, 2007) however, the link between heart rate measurements and energy expenditure is not as strong as other objective techniques (Trost et al., 2001). Heart rate can be measured easily with monitors attached to the wrists and the beltline. The resting and maximal heart rate is compared to gauge exercise and activity intensity. According to the American College of Sports Medicine Position Stand (1998), physical activity intensity according to frequency of heart rate is calculated for practical purposes as shown in Table 1 below:

\begin{tabular}{ccc}
\hline \multirow{2}{*}{ Intensity descriptor } & \multicolumn{2}{c}{ Relative Intensity } \\
\cline { 2 - 3 } & \% Heart rate reserve & Rating of perceived exertion \\
\hline Very light & $<20$ & $<10$ \\
Light & $20-39$ & $10-11$ \\
Moderate & $40-59$ & $12-13$ \\
Vigorous & $60-84$ & $14-16$ \\
Very vigorous & $>85$ & $17-19$ \\
\hline
\end{tabular}

*Adapted from American College of Sports Medicine Position Stand (1998).

Table 1. Physical activity intensity according to frequency of heart rate

Heart rate also has a significant relationship with energy expenditure and has been widely used in studies of physical activity in children (Eston et al., 1998; Spurr et al., 1988; Ceesay et al., 1989; Livingstone et al., 1992). HR monitoring reports much lower levels of physical activity and is based on small sample groups (Livingstone et al., 2003). However there are a 
number of limitations to the use of this technique (Armstrong and Welsman, 2006; Rowlands et al., 1997). Since HR is influenced not only by physical activity, reliability of this measurement is questionable. A child with low levels of physical activity may have high heart rates due to the influence of other parameters such as emotional stress, anxiety, hydration and environment (Armstrong and Welsman, 2006; Rowlands et al., 1997). In this respect, heart rate monitoring should be considered to measure moderate to vigorous physical activity, and heart rates below $120 \mathrm{bpm}$ would be considered to be valid measures of physical activity.

\section{GIS/GPS Tools}

Transportation, urban design and planning studies include Geographic Information Systems (GIS) to support the hypothesis that neighborhood environment is associated with physical activity in the form of walking and biking for transport (Frumkin, 2002; Saelens et al., 2003). GIS tools have been used to describe the associations between objective measures of the built environment and walking and transportation activity (McGinn et al., 2007). In the public health literature, the relationship between the built environment and physical activity was assessed by measuring the frequency, intensity and duration of activity. In such studies, objective measures of the environment were collected and mapped using GIS tools (McGinn et al., 2007). Global positioning system (GPS) is also used to track areas in a settlement or a space in a district where physical activity is promoted (Wheeler et al., 2010; Fjörtoft et al., 2009; Fjörtoft et al., 2010). GPS system was used to record children's movement patterns, which was transferred to GIS systems for further analysis (Fjörtoft et al., 2009; Fjörtoft et al., 2010). The purpose of the studies using GPS tools is to describe the interaction between environment and physical activity; based on the GPS data, designers explore and determine how space may interact with physical activity in children. However, GPS devices fail to record position indoors, under heavy tree canopy and in dense urban areas (Maddison and Ni Mhurchu, 2009) and they have limited accuracy in sensing stationary device location (Chen et al., 2012).

\section{Photography}

Studies of children's geography and social behavior concluded that children's physical activity and use of public spaces have been constricted and controlled (Blades et al., 1998; Matthews et al., 1998). In order to include views of children as key informants of research for their health and well-being, qualitative approaches have been employed (Darbyshire et al., 2005). It is important to offer children the opportunity to portray their own environments and one of the methods used for this purpose is photography, which is commonly accepted and validated by many researchers (Booth and Booth, 2003; Sharples et al., 2003; Wang and Burris, 1997) aiming to generate different and complementary visual information (Darbyshire et al, 2005). In a current study, children were asked to take pictures with disposable cameras (Özdemir, 2010). This visual data production strategy enabled children to relate their everyday life with their activities and environmental perceptions. There is extensive research with children using photography (Aitken and Wingate, 1993; Dodman, 2003; Morrow, 2001; Young and Barrett, 2001). However, there limits of this 
technique; the method of photography did not include children's talk about their taken pictures and the reasons of taking those pictures. Children took pictures and we defined and discussed them as adults.

\section{Schoolyard design to promote physical activity: An exploratory study}

\subsection{Methodology}

This study aims to assess outdoor school environments for their possible association with healthy behavior of children. For this purpose, children's total step counts were associated with the schoolyard size and 1115 students in 4 primary schools were surveyed. The aim of the project is to examine whether size and design of the outdoor school environments affect child physical activity. In addition, gender and age were selected to be variables to determine their relation to physical activity.

A random stratified sampling of primary schools from various districts of the city was used to represent a cross-section of the population. The schools, which have the adequate open space for the renewal projects, are located in different districts in terms of socio-culture and economy, have different numbers of students and need their schoolyards to be renewed, have been selected from a list of elementary schools provided from the Provincial Directorate for National Education (Table 2).

\begin{tabular}{ll}
\hline District & School \\
\hline Çankaya & Kavaklıdere Primary School \\
Mamak & Çocuk Sevenler Primary School \\
Keçiören & Kamil Ocak Primary School \\
Akyurt & TOKİ Primary School \\
\hline
\end{tabular}

Table 2. The primary schools subject to the research and their districts

\subsubsection{Defining landscape characteristics of schoolyards}

For each schoolyard, ordinal categories were used as being applied for the classification of landscape quality. Aerial images and photo surveys were used to assess outdoor school environments; total area, usable area, landscaped-vegetated areas and hard surfaces were measured. The reliability tests of these measurements showed that both measurements on aerial images and hand measurements of a selected schoolyard gave specific and similar results. The photographs describe a variety of outdoor settings suggesting the need for a more spacious space per student after the calculation of the open space standards for school population for each case. Outdoor environments and the adjacent areas were assessed with respect to physical and landscape qualities (i.e. vegetation, material, size). A group of reviewers, which includes landscape architects and architects, reviewed the photographs and scored the schoolyards based on the features such as size, material, vegetation cover, vegetation quality, maintenance and spaciousness. Environments with low physical qualities scored 1 . Environments with advanced features scored 2. 


\subsubsection{Focus groups}

The study also included 30 minutes meetings that were held with the students in each school. These focus groups, targeting children, included discussions on the current problems and future developments of the schoolyards; children's attitudes towards the school settings and the parents' views on their children's use of the schoolyards were discussed. Teachers did not attend the meetings; students had the chance to express their opinions freely.

\subsubsection{Pedometer measurements and BMI value assessments}

Intensity of children's school time activities was measured with electronic pedometers (Omron HJ-12). Pedometers were attached to randomly selected students. Average step counts of 10 children in each school were determined. Measurements also included distance covered, the amount of calorie (kcal) and body oil (gram) burnt during activities. It was assumed that the measurements would be distributed according to age groups, gender and schoolyard size.

Students were asked to indicate their weight and height on the questionnaire sheets to assess their nutritional status. In order to ensure reliability of self-reports, we weighed a group of students using a standard electronic scale, and their heights were measured with a wooden measuring board. Self-reported and objectively measured height and weight status were compared and it was found that self-reports were reliable. The height and weight information obtained in the surveys were used to calculate the BMI, which was computed as weight in kilograms divided by height in meters squared $\left(\mathrm{kg} / \mathrm{m}^{2}\right)$.

BMI values according to age groups are shown below (Table 3) (Uluocak et al., 2006; Şimşek et al., 2005; Öner et al., 2004; Altunkaynak and Özbek, 2007; Uğuz ve Bodur, 2007).

\begin{tabular}{cccccc}
\hline \multirow{2}{*}{ Primary School } & Grade & Age & Underweight & Normal & Overweight \\
\cline { 2 - 6 } & 3 and 4 & $9-10$ & $<14.0$ & $14.0-20.0$ & $>20$ \\
& 5 and 6 & $11-12$ & $<14.6$ & $14.6-23.1$ & $>23.1$ \\
\hline
\end{tabular}

Table 3. BMI values according to age groups

\subsubsection{Photography}

Children's perception of environment was evaluated with photography technique. In this scope, students, selected randomly from each school, were given disposable cameras and were asked to take pictures of places they visit during weekend. It was assumed that children would take pictures of a number of scenes such as greenery, plants, open views, pets, buildings and structures, traffic, indoors and their daily activities. Children's environmental perception would differ according to places they visit such as an urban park or an indoor environment. Based on the picture characteristics, potential perceptual variables were listed after expert ratings of scenes; experts included landscape architects and graduate students. 


\subsubsection{Workshops}

Researchers offered a variety of workshops for school-aged children, teachers and parents. These workshops were oriented towards the respective target audience and based on participatory methods, providing insight into the design process. The aim was to increase environmental awareness among children and to inspire creative thinking. In these workshops, children were introduced to landscape design through presentation, design drawings, sketches and 3D models.

In this case study, after the presentations to the school community, workshops were organized with the voluntary students. Firstly, borders of the schoolyards on the layout plans and draft drawings, entrances, current uses (parking, playfield, etc.) and green fields were shown to the students and they became familiar with the plan. Alternative uses, requested by the students in the schoolyard, were listed. Group of students prepared their own designs. In this process, the researchers assisted the children regarding the drawing techniques. Each project was developed in line with different concepts such as "adventure" or "blossom." First group made an adventure road strolling along the schoolyard. Each member of the second group named her/himself after a flower name and requested these flowers to be planted to the different parts of the schoolyard. The authentic design examples provided at the end of nearly half-hour study were displayed and presented by the group representatives (Figure 3).

Each group prepared a draft plan with sketches and colored markings. The final version of these projects, including before and after images, was displayed on the school boards in order to get feedback from students and teachers (Figure 4 and 5).
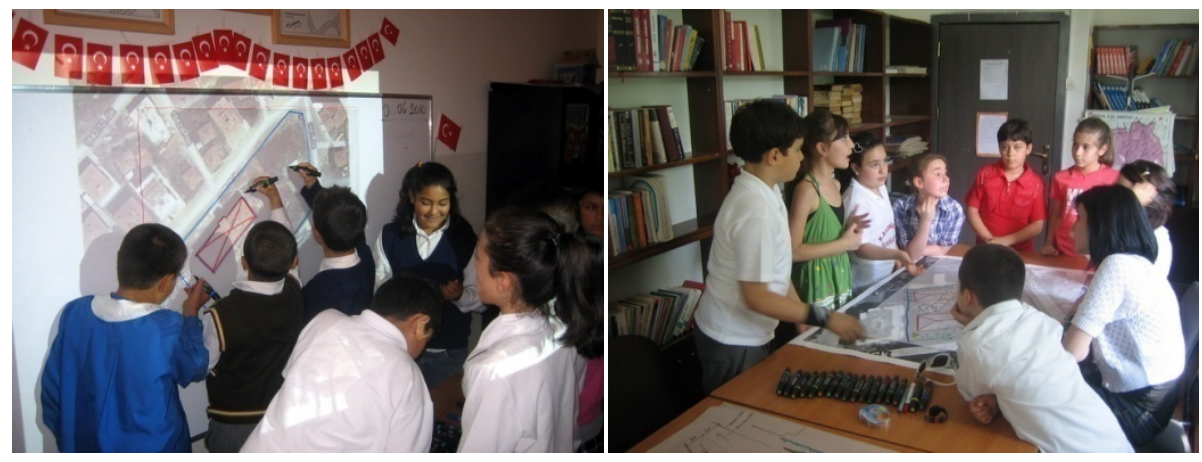

Figure 3. Views from the workshops 

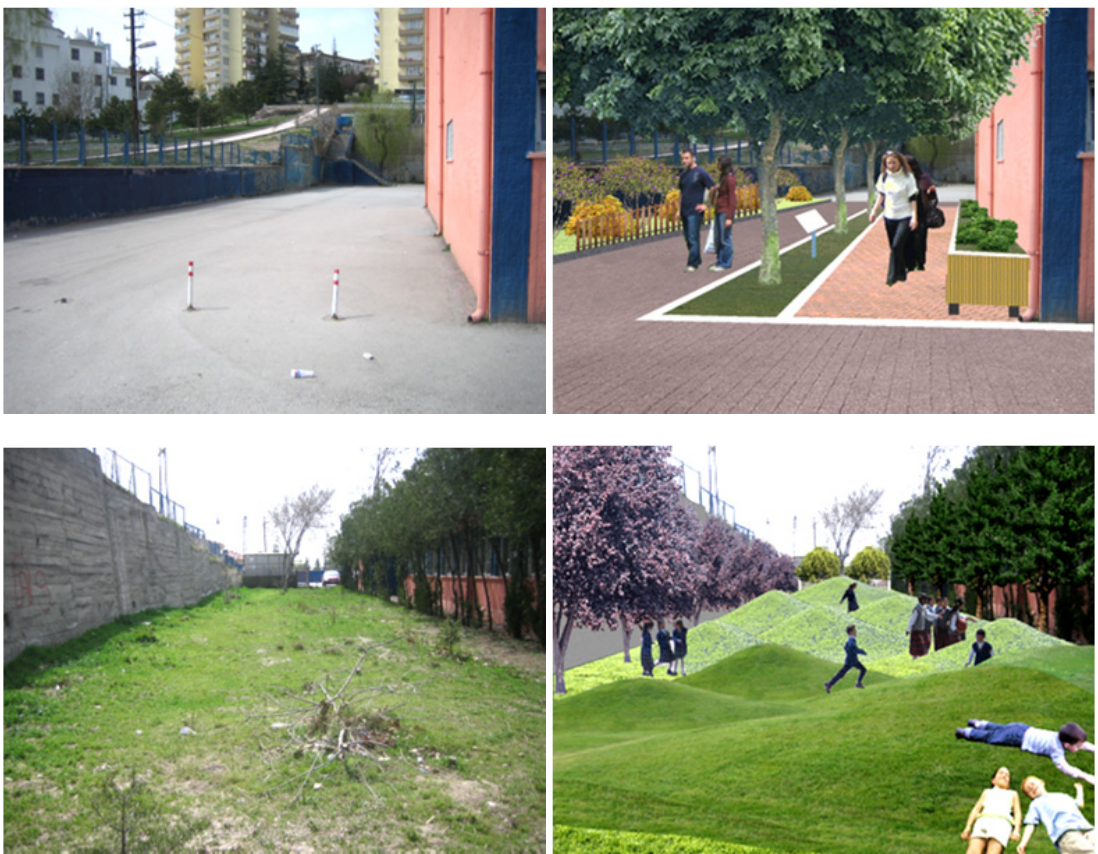

Figure 4. Current status of the schoolyards and the views after the arrangement

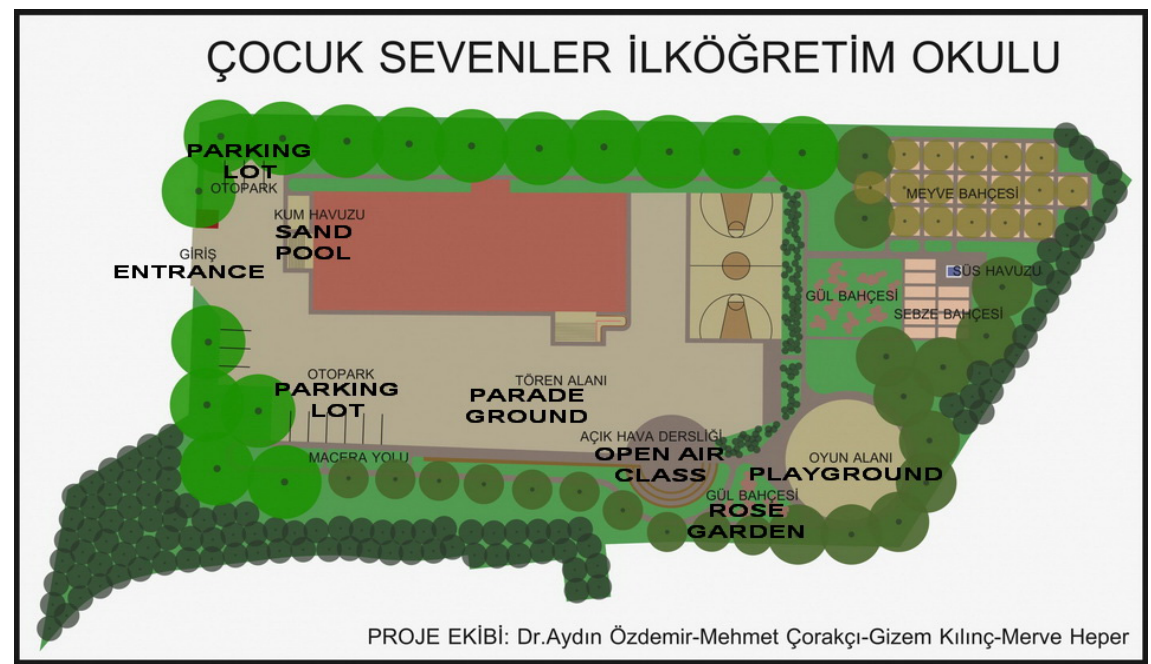

Figure 5. One of the alternative projects include sport facilities, fruit and vegetable gardens, rose garden, parking lot, open-air class, play field and walking trail, as proposed by the children 


\subsection{Results}

Physical and landscape characteristics of schoolyards were defined according to total yard size, total school size, and available space per students as shown in Table 4.

\begin{tabular}{cccccc}
\hline District & School & $\begin{array}{c}\text { Number of } \\
\text { students }\end{array}$ & $\begin{array}{c}\text { Total school } \\
\text { area }\end{array}$ & $\begin{array}{c}\text { Total yard } \\
\text { area }\end{array}$ & $\begin{array}{c}\text { Usable yard } \\
\text { space per } \\
\text { student }\end{array}$ \\
\hline Çankaya & Kavaklidere PS & $650^{*}$ & $2050 \mathrm{~m}^{2}$ & $1350 \mathrm{~m}^{2}$ & $2.08 \mathrm{~m}^{2}$ \\
Mamak & Çocuk Sevenler PS & $580^{*}$ & $5500 \mathrm{~m}^{2}$ & $4750 \mathrm{~m}^{2}$ & $8.19 \mathrm{~m}^{2}$ \\
Keçiören & Kamil Ocak PS & $1300^{*}$ & $9300 \mathrm{~m}^{2}$ & $6800 \mathrm{~m}^{2}$ & $5.23 \mathrm{~m}^{2}$ \\
Akyurt & TOKİ PS & 720 & $6100 \mathrm{~m}^{2}$ & $4525 \mathrm{~m}^{2}$ & $6.28 \mathrm{~m}^{2}$ \\
\hline
\end{tabular}

*The number shows only the morning shift students

Table 4. Physical assessment of schoolyards

Kamil Ocak Primary School has the largest yard; however, the available area per student is not adequate. According to zoning standards in Turkey, child play spaces should have at least $10 \mathrm{~m}^{2}$ usable area per child. This standard is also applicable to schoolyards; however, none of the schools provide sufficient space for child activities in this study (Table 4). Çocuk Sevenler Primary School, which has the largest usable space per student, received the best expert rating score. On the other hand, Kavaklıdere Primary School, which has the smallest and inadequate space per student, received the lowest expert rating score. It is assumed that spatial conditions such as spaciousness influence expert ratings. Kamil Ocak Primary School yard received one of the lowest scores due to the confined feeling and the existence of a high retaining wall that divides the yard into separate lots. This wall was defined as dangerous and useless. Green spaces that have the potential for recreational purposes are out of reach of children and they are not accessible. There is the scarcity of shaded seating spaces and most of the ground is covered with hard material such as asphalt.

\subsubsection{Questionnaires}

Almost half of the respondents were boys $(49,4 \%)$ and 4 th and 5 th graders $(55,6 \%)$. Most of the students have spent at least two years in their school. We may conclude that these students are familiar with the school settings. More than half of the students $(54,8 \%)$ reside in the same neighborhood where the school is located, and most of the students prefer to walk to their schools. Only $22,3 \%$ of respondents commute to school with a vehicle.

There is variability in type of activities during recess. A considerable amount of children spend their recess time inside the school $(13,5 \%)$. More than half of students spend their recess time both indoors and outdoors (59\%). Most of the students prefer to walk in the schoolyard (43,5\%) and $21,2 \%$ of them behave active during recess. On the other hand, only $13,3 \%$ of children in these four schools prefer passive behaviors such as eating and sitting during recess (Figure 6). 


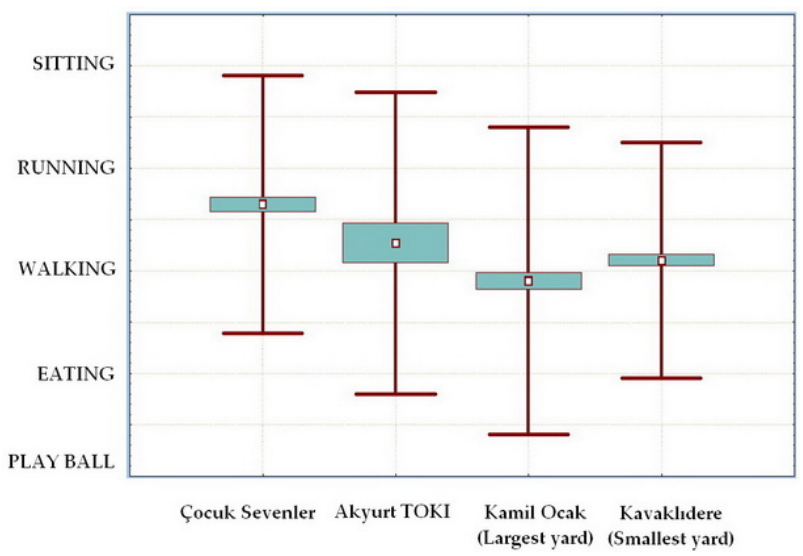

Figure 6. Scatter-plot diagram showing the distribution of type of activities across schools

More than half of respondents define their schoolyards as inadequate for any of the activities (59\%). Regardless of the size of schoolyards, this relationship was found statistically significant $(\mathrm{F}=113.05, \mathrm{df}=3, \mathrm{p}<0.005, \mathrm{R}=0.48)$ (Figure 7).

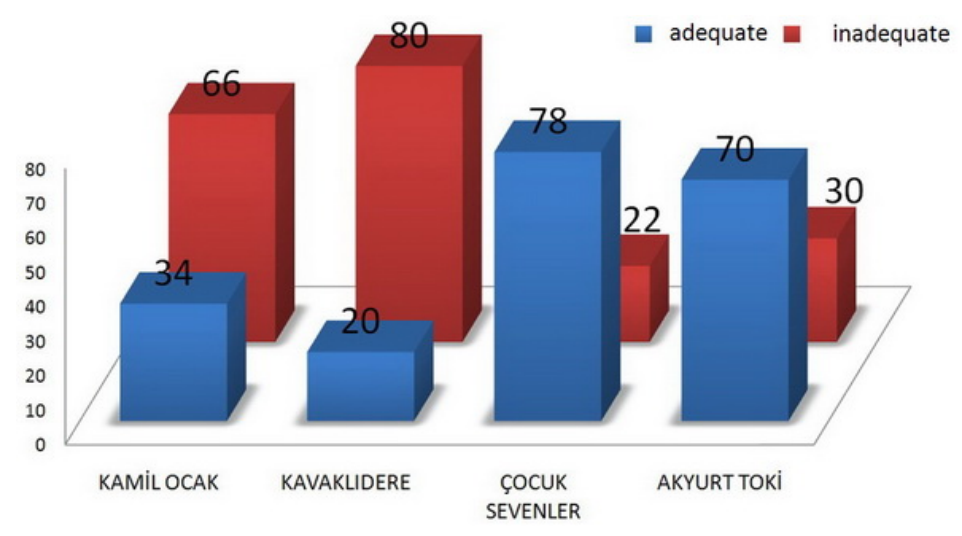

Figure 7. Adequacy of schoolyards

There is a statistical significance among number of students who liked yards; most of the students preferred the larger yards $(\mathrm{F}=226.6, \mathrm{df}=3, \mathrm{p}<0.005, \mathrm{R}=0.60)$. Similar results were identified between the expert ratings and students' responses; children liked the yards which were also highly rated by the experts $(\mathrm{F}=226.6, \mathrm{df}=3, \mathrm{p}<0.005, \mathrm{R}=0.60)$ (Figure 8).

Most of the students (65\%) were not satisfied with the yards. Responses indicated that the size of the yards was a major contributor of this result; most of the children $(34,2 \%)$ did not enjoy the small yards $(\mathrm{F}=16.1, \mathrm{p}<0.05)$. Other reasons included inadequacy of sport facilities and limited green spaces. 


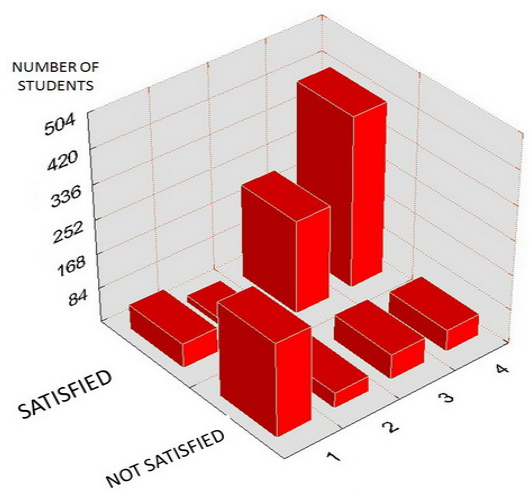

Figure 8. Students' satisfaction of schoolyards among scored yards (Quality scores - 1: High quality; 4: Low quality)

\subsubsection{BMI distribution among schools}

As a result of BMI distribution among schools, $16,2 \%$ of children were defined as overweight $(\mathrm{N}=181)$. Most of the students were in the normal range of BMI values $(78,6 \%$, $\mathrm{N}=876$ ). Boys had higher BMI values than girls, and as expected, BMI values raised according to age groups, except 3rd grade students, which had lower BMI values than 2nd grade students (Table 5).

\begin{tabular}{llcccc}
\hline Domain & & N & Percentage & Mean & sd \\
\hline Gender & Female & 564 & 50.6 & 17.89 & 2.88 \\
& Male & 551 & 49.4 & 18.64 & 2.96 \\
\hline Grade & 2 & 70 & 6.3 & 17.86 & 2.71 \\
& 3 & 215 & 19.2 & 17.30 & 2.79 \\
& 4 & 303 & 27.2 & 18.15 & 2.86 \\
& 5 & 317 & 28.4 & 18.62 & 2.98 \\
& 6 & 210 & 18.8 & 18.99 & 2.93 \\
\hline BMI & Underweight & 58 & 5.2 & & \\
& Normal & 876 & 78.6 & & \\
& Overweight & 181 & 16.2 & & \\
\hline Type of & Walk & 866 & 77.7 & 18.20 & 2.95 \\
commute & & & & & \\
& Vehicle & 249 & 22.3 & 18.47 & 2.87 \\
\hline Yard size & Kamil Ocak (Largest yard) & 293 & & 18.17 & 2.75 \\
& Çocuk Sevenler & 293 & & 17.58 & 2.88 \\
& TOKI Akyurt & 55 & & 18.13 & 2.73 \\
& Kavaklidere (Smallest yard) & 474 & & 18.75 & 3.02 \\
\hline
\end{tabular}

Table 5. Subject characteristics and BMI values 
Results showed that there is a statistical significance between type of activities and BMI values $(\mathrm{F}=2.67, \mathrm{P}=0.032)$. Students who were active during recess had lower $\mathrm{BMI}$ values than passive students. This was similar with the active school commuters; children who actively commute to school have lower BMI values, and this result is statistically significant $(F=3.78$, $\mathrm{df}=1, \mathrm{p}=0.013$ ). Interestingly, large schoolyards have limited influence on decreased BMI values. Children in smaller schoolyards were more active and had lower BMI values. This finding is assessed by the relationship between total step counts and yard sizes, which is presented in the next section.

\subsubsection{Pedometer measurements}

A total of 120 measurements were made to indicate the variations in daily step counts, distance covered, burnt calories and fat among children at ages between 9 and 11 (Table 6).

\begin{tabular}{|c|c|c|c|c|c|c|c|c|c|c|c|}
\hline & & $\mathbf{N}$ & $\%$ & $\begin{array}{l}\text { Step } \\
\text { count }\end{array}$ & sd & $\begin{array}{c}\text { Distance } \\
(\mathbf{k m})\end{array}$ & sd & $\begin{array}{c}\text { Burnt calorie } \\
\text { (Kcal) }\end{array}$ & sd & $\begin{array}{l}\text { Burnt } \\
\text { fat (gr) }\end{array}$ & sd \\
\hline \multirow{2}{*}{ 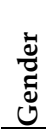 } & Female & 65 & 55 & 4201.7 & 1971 & 2.43 & 1.19 & 66.6 & 33.9 & 3.75 & 2.01 \\
\hline & Male & 55 & 45 & 4609.5 & 2068 & 2.75 & 1.25 & 84.1 & 41.8 & 4.71 & 2.48 \\
\hline \multirow{4}{*}{ 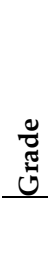 } & 3 & 10 & 8 & 5605 & 2970.8 & 3.32 & 1.91 & 82.5 & 51.1 & 4.85 & 3.2 \\
\hline & 4 & 40 & 34 & 4839 & 2041.7 & 2.81 & 1.32 & 74.6 & 34.3 & 4.17 & 1.95 \\
\hline & 5 & 70 & 58 & 3957 & 1734.4 & 2.34 & 0.96 & 73.4 & 39.3 & 4.1 & 2.32 \\
\hline & $\begin{array}{l}\text { Kamil Ocak } \\
\text { (Largest yard) }\end{array}$ & 40 & 33 & 3645.8 & 2171.6 & 2.23 & 1.34 & 61.18 & 36.9 & 3.46 & 2.24 \\
\hline \multirow{2}{*}{ 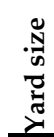 } & Çocuk Sevenler & 40 & 33 & 4173.7 & 1585.7 & 2.49 & 1.02 & 61.1 & 27.3 & 3.6 & 1.54 \\
\hline & $\begin{array}{l}\text { Kavaklıdere } \\
\text { (Smallest yard) }\end{array}$ & 40 & 33 & 5346.4 & 1914.7 & 3.01 & 1.76 & 97.5 & 40.1 & 5.5 & 2.4 \\
\hline
\end{tabular}

Table 6. Step counts, distance, burnt fat and calorie across gender, grades, and yard sizes

Average step counts were 5346 in Kavaklıdere, 4174 in Çocuk sevenler, 3646 in Kamil Ocak primay schools. Boys were more active than girls, and small children were more active than older ones. Similar results were found for values of energy expenditure; boys and small children burnt more calorie and fat than girls and older students. The most interesting outcome of the study was the statistical significant and inverse relationship between schoolyard size and pedometer counts. Children in small schoolyards walked more $(\mathrm{F}=4.47, \mathrm{df}=2, \mathrm{p}=0.013)$, and burnt more calories $(\mathrm{F}=12.83, \mathrm{df}=2, \mathrm{p}<0.05)$ and fat $(\mathrm{F}=11.78, \mathrm{df}=2$, $\mathrm{p}<0.05$ ). 


\subsubsection{Assessment of student pictures}

Total of 472 pictures taken by students were assessed as shown in Table 7. Experts defined type of images and visible elements in the pictures. As a control group, researcher took pictures with a disposable camera and included these images within other groups of images for a random presentation. Both control group images and student images were similarly assessed, which conclude that assessments are reliable and valid.

\begin{tabular}{|c|c|c|c|c|c|c|c|c|}
\hline School & Gender & Total & Built & Planting & Enclosed & $\begin{array}{l}\text { Open } \\
\text { scene }\end{array}$ & $\begin{array}{l}\text { Scene- } \\
\text { plants }\end{array}$ & Animals \\
\hline \multirow{7}{*}{ 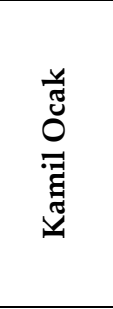 } & $\mathbf{F}$ & 19 & 4 & & 5 & 2 & 8 & \\
\hline & F & 15 & 2 & 7 & 1 & 2 & 3 & \\
\hline & F & 20 & 3 & 8 & 1 & & 8 & \\
\hline & F & 27 & 5 & 3 & & 1 & 13 & 5 \\
\hline & $\mathbf{F}$ & 20 & 3 & 8 & 1 & & 8 & \\
\hline & M & 22 & 1 & 7 & 1 & & 8 & 5 \\
\hline & M & 25 & 1 & 16 & & 3 & 4 & 1 \\
\hline \multirow{9}{*}{ 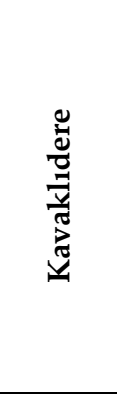 } & $F$ & 25 & 2 & 19 & & & & 4 \\
\hline & F & 22 & 1 & 6 & 5 & & 5 & 5 \\
\hline & F & 25 & 1 & 3 & 1 & & 20 & \\
\hline & F & 23 & & 7 & 4 & & 9 & 3 \\
\hline & F & 18 & 3 & 8 & 4 & & 3 & \\
\hline & $\mathrm{F}$ & 25 & 1 & 14 & 2 & 1 & 4 & 3 \\
\hline & $\mathrm{F}$ & 15 & 4 & 4 & 5 & 1 & 1 & \\
\hline & M & 20 & & 10 & 1 & 3 & & 6 \\
\hline & $\mathrm{M}$ & 21 & 1 & 6 & 2 & & 7 & 5 \\
\hline \multirow{6}{*}{ 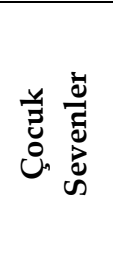 } & $\mathrm{F}$ & 23 & 2 & 11 & 2 & & 8 & \\
\hline & F & 16 & 1 & 8 & 4 & 1 & 2 & \\
\hline & $\mathrm{F}$ & 20 & & 3 & 6 & 7 & 4 & \\
\hline & $\mathrm{F}$ & 17 & & & 1 & 5 & 8 & 3 \\
\hline & $\mathrm{F}$ & 27 & 1 & 10 & 9 & 4 & 3 & \\
\hline & $\mathrm{M}$ & 27 & 2 & 8 & 5 & 12 & & \\
\hline
\end{tabular}

Table 7. Number of pictures according to the picture character across schools

Most of the students took pictures of plants and plant groups (35\%). A considerable number of students took landscape images (27\%). Only $12 \%$ of children captured interior spaces such as their home environments and school interiors. The most frequent type of images was captured from a vantage point-balcony or a terrace-looking toward the green spaces and plant groups. Although most of the images were captured during weekend, most of the pictures included home environments and local parks. We may conclude that children spend their weekend time at home and in the neighborhood. 
Distribution of image properties are associated with regional locations (Figure 9). Kavaklidere Primary School is located in a highly dense region with dense traffic and limited green spaces. Local parks in the district are scarce and limited front yards of apartments are used for parking cars. Kamil Ocak Primary School, on the other hand, is located in a district with lower dense housing distribution. This neighborhood with lower income families has more open spaces and green lots. Students' perceptions of environment, therefore, may vary according to the neighborhood characteristics. Most of the students in Kavaklidere Primary School took pictures of plants in their homes. On the other hand, Kamil Ocak and Çocuk Sevenler students took pictures of open spaces and open vistas. These results can be associated with neighborhood characteristics. However, these assumptions should be based on valid and systematic research that should include significant comparisons of children's environmental perceptions and spatial characteristics of neighborhoods.

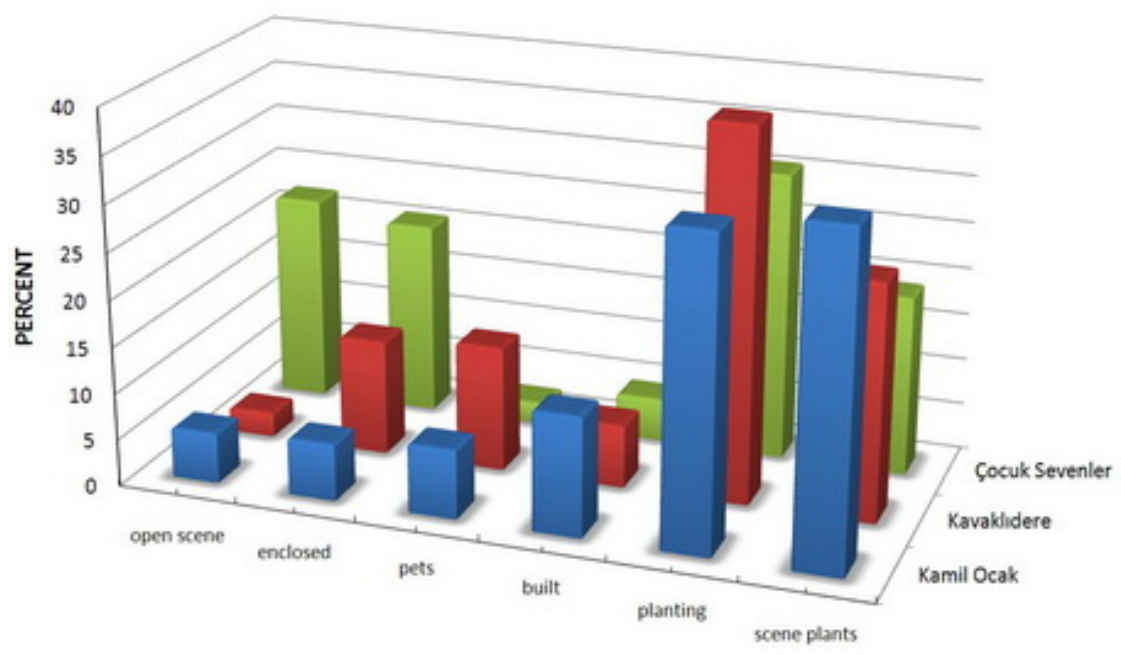

Figure 9. Distribution of picture properties across schools

\subsection{Discussion}

The results of this study contribute to both health and design professionals; environmental variables are effective in health promotion. In terms of design outcomes, this study provides evidence indicating the spatial effects of school environments on child health. Although most schools lack spacious schoolyards that were defined as mostly crowded and congested during recess, children were more active in small yards. Students generally complain about limited outdoor space for both play and physical activities; most students requested more spacious and green space for attraction and comfort. On the contrary of the expectations, pedometer measurements provided support that space distribution rather than the size is effective in health promotion. As many children attend to public schools, improvement the quality of the schoolyards to promote more physical activities is recommended. 
It was expected that larger yards would improve health of students with lower BMI values, which was found in the study of Özdemir and Yilmaz (2008). However, this study found a statistical significant and inverse relationship between schoolyard size and pedometer counts. Children in smaller schoolyards were more active with more step counts. The findings from the questionnaires, which included assessment of BMI values showed similar results; children in schools with smaller yards are more active and have lower BMI values.

The schools are considered for the purpose of this study in the small to medium size bracket. The current study questionnaire sample would appear to be representative in terms of school size and regional distribution. Data in the present study indicate that small schools reported more positive physical activity promoting practices than larger schools. Small schools experienced fewer barriers than larger schools specifically with respect to restricted areas, accessibility, supervision, security and availability of play equipments. Small schoolyards may provide more opportunities for mixed and group plays and the limited availability of space may promote children to be more active. Children in small schoolyards all play together, rather than being in separate groups in larger yards. However, these factors were not included in this study, which requires further investigation.

On the other hand, larger schoolyards were more likely to permit children to play on the green areas, which are generally allocated for cars. These schools also permit the free-play of children during recess for security and health reasons; teachers are generally worried about the possible injury of children on vast and vacant yards. Meanwhile in larger schoolyards, children were more likely to engage in group activities. Since these schools lack fixed equipments and playground markings, children stroll around during recess. Barriers in the large yards such as walls, fences and parked cars limit the active behavior of children.

The findings of this study are relevant to Zask et al. (2001)'s results that as schools got larger children became less active. On the other hand, the pedometer measurements of Cardon et al. (2008) and Louie and Chan (2003) indicated that more space per child was found to be associated with more PA during recess; children in schools with large outdoor space were significantly more active than children at schools with smaller outdoor space. The present study would indicate that the comparison of yard sizes exhibit different challenges in relation to play habits, yard organization, and availability of play equipments, crowding, landscaping, maintenance and most importantly effects on physical activity and child health. More research is needed to investigate possible relations between these factors in order to overcome these challenges and to decide whether yard size is influential on child health.

Children who were active during recess had lower BMI values than passive students. This finding is similar with the active school commuters; children who actively commute to school have lower BMI values. The study also found gender and age differences; boys have higher BMI values than girls, and as expected, BMI values rise according to age groups, except 3rd grade students, which have lower BMI values than 2nd grade students. Boys and small children burnt more calorie and fat than girls and older students. More boys were engaged in active behavior than girls and similar findings were consistently reported in 
other studies (Myers et al., 1996; Sallis et al., 2000; Mota et al., 2005; Tudor-Locke et al., 2006; Özdemir and Yilmaz, 2008).

\subsection{Conclusions}

Given the increasing rates of childhood obesity, energy expenditure is a research priority to improve settings promoting more activity. The effect of the built environment on health is a current research agenda and research has found associations between environmental features and physical activity and body mass. However, the examination of physical environments to explain and promote physical activity is an important yet underinvestigated area of research inquiry, and research on health outcomes of the physical environment has been limited by insufficient data regarding the role of the environment.

Many factors contribute to obesity, and the physical environment in particular can have a strong influence on children's opportunities for regular physical activity. Decisions made at the local level regarding planning and design of school environments can have a significant impact on child health. By recognizing these links, communities can help reverse obesity trends and build healthy environments. Young children appear to engage in low levels of physical activity at school. With more than 25 millions of children attending schools in Turkey, it is important to better understand factors inherent in school environment that influence physical activity behaviors of young children.

Major critical factor emerged from this investigation was the spaciousness is not a critical measure for an active behavior as well as for play and learning. Almost all students had complaints about the lack of adequate space for play due to the crowded schoolyard in all recess time. However small spaces may promote more active behavior and public schools with limited space inside the city centers can better develop design guidelines to improve the physical qualities of these yards.

Previous studies have shown the impact of outdoor environments on physical activity and prevention from obesity in various nations, and the recognition of such approach may lead to the advancement of the outdoor school environments. Encouraging students to be active in safe and attractive outdoor environments may be accomplished by careful and systematic landscape designs, but the major concerns are the finance and the maintenance.

The urban environment is not built to suit child needs and to accommodate child play behaviors in a safe environment. The most natural way to be active and to develop healthy attitudes in PA among children is to play outside in a safe and open environment (Caroli et al., 2011), and the school environment is one of the settings to provide safe and healthy environment for children. School setting is a valuable resource contributing improved PA and this type of environment should be studied to find ways of reducing obesity by improving active behavior. Research should include identification of environmental variables of schools contributing to high levels of obesity in children. Schools in neighborhoods with high risks of obesity should be the focus of future studies; those school settings should be re-developed and re-designed to encourage PA in children. 
It is assumed that findings would reinforce the need to provide and support school physical environments related to physical activity. The results of exploratory studies indicate support for the contention that child spaces should be thought of as a part of a viable strategy for health promotion. The hypothesis is that outdoor environments with more natural landscape characteristics are a viable context for health promotion activities such as physical activity.

A conceptual framework should be outlined that addresses the complexity of the relationship between spatial characteristics of outdoor environments and students' physical activity behavior, which should be structured to guide future policy and research.

Active behaviors should be promoted with city planning and infrastructure by creating safe and accessible urban environments. Changes in neighborhood characteristics, adding more parks, safe walking routes and playgrounds and recreational facilities will have positive effects on health of children and adults.

\subsection{Future directions}

Research is needed to develop effective interventions to increase daily physical activity via active commute to school, monitoring daily physical activity behaviors, promoting school activity programs and promoting healthy curriculum and dietary habits. Studies should include more objective measurements of physical activity among different age groups and the specific roles of environmental factors should be defined that are related to preventing childhood obesity (Lobstein et al., 2004). School environment represents a fundamental opportunity for children to gain active lifestyle through the use of spaces that promote active behavior (Pate et al., 2006; Wagner and Kirch, 2006). Schools are ideal places for health promotion by including healthy school programs, curriculums and making availability of daily exercise (Stice et al., 2006; Doak et al., 2006; Brown et al., 2009). Research should include identification of environmental variables of schools contributing to high levels of obesity in children. Schools in neighborhoods with high risks of obesity should be the focus of future studies; those school settings should be re-developed and re-designed to encourage physical activity focusing on minority and disadvantaged groups and communities.

Research should include longitudinal approach to track changes in children's activities, and include sample from rural and remote areas with disadvantaged neighborhoods. Changes in neighborhood characteristics, adding more parks, safe walking routes and playgrounds and recreational facilities will have positive effects on health of children. Promoting physical activity in urban neighborhoods, especially lower income ones, must address concerns about the physical and social environment.

\subsection{Strengths and limitations}

The key strengths of this study are the use of measured height and weight for the calculation of BMI, the objective measurement of the PA by pedometers and the adoption of 
BMI cut-off points for children. This use of objective measurement of PA reduces the bias commonly associated with self-report measures. The sample selected is a good representative of the population; schools were randomly selected according to regions and a considerable number of students were included in the study in each school.

This study was conducted during spring season only, and children were more likely to be outside with active behaviors which resulted with limited variability in the outcomes. Another limitation of our study is the presentation of results from a single time point, which limits the casual directions in the relationships between overweight and well-being. In our study, there may be too many other external factors in the setting - the schoolyards - which are difficult to measure and available to include as independent factors affecting health of children.

As with all questionnaire-based surveys, social desirability bias in the responses is a problem; children may have difficulties in recalling types of behavior they participated in the last two weeks.

Studies that define the casual relationships between environmental interventions and health behaviors with empirical associations usually lack definitions on how and why these variables influence health behaviors, which is one of the limitations of this study.

Based on these limitations, more systematic research is needed on developing strategies to prevent childhood obesity, to find ways in promoting more active behavior and to better design environments for improving child health.

\section{Author details}

Aydin Özdemir

Ankara University, Faculty of Agriculture, Department of Landscape Architecture, Turkey

\section{Acknowledgement}

This study; "Schoolyard Design to Promote Physical Activity: An Exploratory Study" was supported by a grant from the Scientific Research Projects Coordination Unit, Ankara University, Turkey (BAP-09Ö4347001). The author is grateful for the help and support of Mehmet Çorakçı, Gizem Kılınç, Merve Heper and Filiz Uncu who worked with the author in the development and design of this case study.

\section{References}

Aarts, M.J., de Vries, S.I., van Oers, H.A. and Schuit, A.J. (2012). Outdoor play among children in relation to neighborhood characteristics: a cross-sectional neighborhood observation study. International Journal of Behavioral Nutrition and Physical Activity, 17(9), 98. 
Affuso, O., Stevens, J., Catellier, D., McMurray, R.G., Ward, D.S., Lytle, L., et al. (2011). Validity of self-reported leisure-time sedentary behavior in adolescents. Journal of Negative Results in Biomedicine, 10, 2.

Ainslie, P.N., Reilly, T. and Westerterp, K.R. (2003). Estimating human energy expenditure: a review of techniques with particular reference to doubly labelled water. Sports Medicine, 33(9), 683-698.

Aitken, S.C. and Wingate, J. (1993). A preliminary-study of the self-directed photography of middle-class, homeless, and mobility-impaired children. Professional Geographer, 45(1), 65-72.

Alhassan, S., Sirard, J. R. and Robinson, T. N. (2007). The effects of increasing outdoor play time on physical activity in Latino preschool children. International Journal of Pediatric Obesity, 2, 153-158.

Al-Hazzaa, H. (2007). Pedometer-determined physical activity in obese and non-obese boys 8-12 years. Journal of Physiological Anthropology, 26, 459-465.

Altunkaynak, B.Z. and Özbek, E. (2007). Obezite: nedenleri ve tedavi seçenekleri. Dicle Tıp Dergisi, 34(2), 144-149.

American College of Sports Medicine Position Stand. (1998). The recommended quantity and quality of exercise for developing and maintaining cardiorespiratory and muscular fitness, and flexibility in healthy adults. Medicine and Science in Sports and Exercise, 30(6), 975-991.

Anderson, P.M. and Butcher, K.E. (2006). Childhood obesity: trends and potential causes. The Future of Children, 16(1), 19-45.

Armstrong, N. and Welsman, J.R. (2006). The physical activity patterns of European youth with reference to methods of assessment. Sports Medicine, 36(12), 1067-1086.

Babbie, E. (2006). The Practice of Social Research. New York: Wadsworth Publishing.

Badland, H. and Schofield, G. (2005). Transport, urban design, and physical activity: an evidence-based update. Transportation Research Part D: Transport and Environment, 10(3), 177-196.

Bailey, D.A. (1995). The role of mechanical loading in the regulation of skeletal development during growth. In: C.J.R. Blimkie and O. Bar-Or (Eds.), New Horizons in Pediatric Exercise Science (pp. 97-108). Champaign, IL: Human Kinetics.

Baranowski, T. and Jago, R. (2005). Understanding the mechanisms of change in children's physical activity programs. Exercise and Sport Sciences Reviews, 33(4), 163-168.

Bassett, D.R. and John, D. (2010). Use of pedometers and accelerometers in clinical populations: validity and reliability issues. Physical Therapy Reviews, 15(3), 135-142.

Bell, J.F., Wilson, J.S. and Liu, G.C. (2008). Neighborhood greenness and 2-year changes in body mass index of children and youth. American Journal of Preventive Medicine, 35(6), 547-553.

Bennett, G.G., McNeill, L.H., Wolin, K.Y., Duncan, D.T., Puleo, E. and Emmons, K.M. (2007). Safe to walk? Neighborhood safety and physical activity among public housing residents. PLoS Medicine, 4(10), e306.

Berenson, G.S. (1986). Evolution of cardiovascular risk factors in early life: perspectives on causation. In: G.S. Berenson (ed.), Causation of Cardiovascular Risk Factors in Children, New York: Raven Press, pp. 1 -26. 
Berlin, J.E., Storti, K.L. and Brach, J.S. (2006). Using activity monitors to measure physical activity in free-living conditions. Physical Therapy, 86(8), 1137-1145.

Biddle, S., Sallis, J.F. and Cavill, N.A. (1998). Young and active? Young People and Health Enhancing Physical Activity: Evidence and Implications. London: Health Education Authority.

Black, M.M. and Krishnakumar, A. (1998). Children in low-income, urban settings: interventions to promote mental health and well-being. American Psychologists, 53(6), 635-646.

Blades, M., Blaut, J.M., Darvizeh, Z., Elguea, S., Sowden, S., Soni, D., Spencer, C., Stea, D., Surajpaul, R. and Uttal, D. (1998). A cross-cultural study of young children's mapping abilities. Transactions of the Institute of British Geographer, 23(2), 269-277.

Bonnefoy, J., Morgan, A., Kelly, M.P., Butt, J. and Bergman, V. (2007). Constructing the evidence base on the social determinants of health: a guide. National Institute for Health and Clinical Excellence. Retrieved on December, 18, 2012. http://www.who.int/social_determinants/knowledge_networks/add_documents/mekn_ final_guide_112007.pdf

Booth, T. and Booth, W. (2003). In the frame: photovoice and mothers with learning difficulties. Disability and Society, 18(4), 431-42.

Branas, C.C., Cheney, R.A., MacDonald, J.M., Tam, V.W., Jackson, T.D. and Ten Have, T.R. (2011). A difference-in-difference analysis of health, safety, and greening vacant urban space. American Journal of Epidemiology, 174(11), 1296-1306.

Brink, L.A., Nigg, C.R., Lampe, S.M., Kingston, B.A., Mootz, A.L. and van Vliet, W. (2010). Influence of schoolyard renovations on children's physical activity: the Learning Landscapes Program. American Journal of Public Health, 100(9), 1672-1678.

Brown, W.J., Bauman, A.E. and Owen, N. (2009). Stand up, sit down, keep moving: turning circles in physical activity research? British Medical Journal, 43(2), 86.

Brug, J., Oenema, A. and Ferreira, I. (2005). Theory, evidence and Intervention Mapping to improve behavior nutrition and physical activity interventions. International Journal of Behavioral Nutrition and Physical Activity, 2(1), 2.

Cardon, G., Van Cauwenberghe, E., Labarque, V., Haerens, L. and De Bourdeaudhuij, I. (2008). The contribution of preschool playground factors in explaining children's physical activity during recess. International Journal of Behavioral Nutrition and Physical Activity, 5(1), 11.

Carnegie, M.A., Bauman, A., Marshall, A.L., Mohsin, M., Westley-Wise, V. and Booth, M.L. (2002). Perceptions of the physical environment, stage of change for physical activity, and walking among Australian adults. Research Quarterly for Exercise and Sport, 73(2), 146-155.

Ceesay, S.M., Prentice, A.M., Day, K.C., Murgatroyd, P.R., Goldberg, G.R., Scott, W. and Spurr, G.B. (1989). The use of heart rate monitoring in the estimation of energy expenditure: a validation study using indirect whole-body calorimetry. British Journal of Nutrition, 61(2), 175-186.

Chao, H.J., Schwartz, J., Milton, D.K. and Burge, H.A. (2003). The work environment and workers' health in four large office buildings. Environmental Health Perspectives, 111(9), 1242. 
Chaput, J.P., Klingenberg, L., Astrup, A. and Sjodin, A.M. (2011). Modern sedentary activities promote overconsumption of food in our current obesogenic environment. Obesity Reviews, 12(5), 12-20.

Chen, K.Y., Janz, K.F., Zhu, W. and Brychta, R.J. (2012). Re-defining the roles of sensors in objective physical activity monitoring. Medicine and Science in Sports and Exercise, 44(1), 13-23.

Cooper, A.R., Wedderkopp, N., Jago, R., Kristensen, P.L., Moller, N.C., Froberg, K., Page, A.S. and Andersen, L.B. (2008). Longitudinal associations of cycling to school with adolescent fitness. Preventive Medicine, 47(3), 324-328.

Cooper-Marcus, C. and Barnes, M. (1999). Healing Gardens: Therapeutic Benefits and Design Recommendations. New York: John Wiley and Sons.

Corder, K., Ekelund, U., Steele, R.M., Wareham, N.J. and Søren Brage, S. (2008). Assessment of physical activity in youth. Journal of Applied Physiology, 105(3), 977-987.

Cradock, A.L., Melly, S.J., Allen, J.G., Morris, J.S. and Gortmaker, S.L. (2007). Characteristics of school campuses and physical activity among youth. American Journal of Preventive Medicine, 33(2), 106-113.

Cunningham, G.O. and Michael, Y.L. (2004). Concepts guiding the study of the impact of the built environment on physical activity for older adults: a review of the literature. American Journal of Health Promotion, 18(6), 435-443.

Dahlgren, G. and Whitehead, M. (1991). Policies and Strategies to Promote Equity in Health. Stockholm : Institute for Future Studies.

Daniels, S.R. (2006). The consequences of childhood overweight and obesity. Future Child, 16(1), 47-67.

Daniels, S.R., Arnett, D.K., Eckel, R.H., Gidding, S.S., Hayman, L.L., Kumanyika, S. and Williams, C.L. (2005). Overweight in children and adolescents pathophysiology, consequences, prevention, and treatment.Circulation, 111(15), 1999-2012.

Darbyshire, P., MacDougall, C. and Schiller, W. (2005). Multiple methods in qualitative research with children: more insight or just more? Qualitative research, 5(4), 417-436.

Davis, A. and Jones, L.J. (1996). Children in the urban environment: an issue for the new public agenda. Health and Place, 2(2), 107-113.

Davison, K.K. and Lawson, C.T. (2006). Do attributes in the physical environment influence children's physical activity? A review of the literature. International Journal of Behavioral Nutrition and Physical Activity, 3(1), 19.

Debus, M. (1990). Handbook for Excellence in Focus Group Research. Washington, DC: Academy for Educational Development.

De Jong, K., Albin, M., Skärbäck, E., Grahn, P., Wadbro, J., Merlo, J. and Björk, J. (2011). Area-aggregated assessments of perceived environmental attributes may overcome single-source bias in studies of green environments and health: results from a crosssectional survey in southern Sweden. Environmental Health, 10(1), 4.

Dietz, W.H. (1998). Health consequences of obesity in youth: childhood predictors of adult disease. Pediatrics, 101(3 Pt 2), 518-525.

Din-Dzietham, R., Liu, Y., Bielo, M.V. and Shamsa, F. (2007). High blood pressure trends in children and adolescents in national surveys, 1963 to 2002. Circulation, 116(13), 14881496. 
Dishman, R.K. and Sallis, J.F. (1994). Determinants and interventions for physical activity and exercise. In: C. Bouchard, R.J. Shephard and T. Stephens (Eds.), Physical Activity, Fitness and Health: International Proceedings and Consensus Statement (pp. 214-238). Champaign, IL: Human Kinetics.

Doak, C.M., Visscher, T.L.S., Renders, C.M. and Seidell, J.C. (2006). The prevention of overweight and obesity in children and adolescents: a review of interventions and programs. Obesity Reviews, 7(1), 111-136.

Dodman, D.R. (2003). Shooting in the city: an autophotographic exploration of the urban environment in Kingston, Jamaica. Area, 35(3), 293-304.

Dyment, J.E. and Bell, A.C. (2007). Active by design: promoting physical activity through school ground greening. Children's Geographies, 5(4), 463-477.

Dyment, J.E., Bell, A.C. and Lucas, A.J. (2009). The relationship between school ground design and intensity of physical activity. Children's Geographies, 7(3), 261-276.

Ebbeling, C.B., Pawlak, D.B. and Ludwig, D.S. (2002). Childhood obesity: public-health crisis, common sense cure. Lancet, 360(9331), 473-482.

Eisenmann, J.C., Laurson, K.R., Wickel, E.E., Gentile, D. and Walsh, D. (2007). Utility of pedometer step recommendations for predicting overweight in children. International Journal of Obesity, 31(7), 1179-1182.

Eiser, C. and Morse, R. (2001). Can parents rate their child's health related quality of life? Results of a systematic review. Quality of Life, 10(4), 347-357.

Eiser, C., Mohay, H. and Morse, R. (2000). The measurement of quality of life in young children. Child: Care, Health and Development, 26(5), 401-414.

Ekelund, U., Sjostrom, M., Yngve, A., Poortvliet, E., Nilsson, A., Froberg, K., Wedderkopp, N. and Westerterp, K. (2001). Physical activity assessed by activity monitor and doubly labelled water in children. Medicine and Science in Sports and Exercise, 33(2), 275-281.

Ellaway, A., Macintyre, S. and Bonnefoy, X. (2005). Graffiti, greenery, and obesity in adults: secondary analysis of European cross-sectional survey. British Medical Journal, 331(7517), 611-612.

Engelbrektsson, P. (2002). Effects of product experience and product presentations in focus group interviews. Journal of Engineering Design, 13(3), 215-221

Ernst, M. P. and Pangrazi, R. P. (1999). Effects of a physical activity program on children's activity levels and attraction to physical activity. Pediatric Exercise Science, 11, 393-405.

Eston, R. G., Rowlands, A. V. and Ingledew, D. K. (1998). Validity of heart rate, pedometry, and accelerometry for predicting the energy cost of children's activities. International Journal of Applied Physiology, 84 (1), 362-371.

Evans, G.W., Wells, N.M. and Moch, A. (2003). Housing and mental health: A review of the evidence and a methodological and conceptual critique. Journal of Social Issues, 59(3), 475-500.

Everett Jones, S., Brener, N.D. and McManus, T. (2003). Prevalence of school policies, programs, and facilities that promote a healthy physical school environment. American Journal of Public Health, 93(9), 1570-1575.

Faulkner, G.E.J., Buliung, R.N., Flora, P.K. and Fusco, C. (2009). Active school transport, physical activity levels and body weight of children and youth: a systematic review. Preventive Medicine, 48(1), 3-8. 
Feng, J., Glass, T.A., Curriero, F.C., Stewart, W.F. and Schwartz, B.S. (2010). The built environment and obesity: a systematic review of the epidemiologic evidence. Health Place, 16(2), 175-190.

Ferreira, I., Van der Horst, K., Wendel-Vos, W., Kremers, S., Van Lenthe, F.J. and Brug, J. (2007). Environmental correlates of physical activity in youth: a review and update. Obesity Reviews, 8(2), 129-154.

Fjörtoft, I., Kristoffersen, B. and Sageie, J. (2009). Children in schoolyards: tracking movement patterns and physical activity using global positioning system and heart rate monitoring. Landscape Urban Planning, 93(3-4), 210-217.

Fjörtoft, I., Lofman, O. and Halvorsen Thoren, K. (2010). Schoolyard physical activity in 14year-old adolescents assessed by mobile GPS and heart rate monitoring analyzed by GIS. Scandinavian Journal of Public Health, 38(5), 28-37.

Flavia, B., Meyer, U., Niederer, I., Ebenegger, V., Marques-Vidal, P., Granacher, U. and Koebnick, C. (2010). Socio-cultural determinants of adiposity and physical activity in preschool children: A cross-sectional study. BMC Public Health, 10.

Frank, L., Schmid, T., Sallis, J., Chapman, J. and Saelens, B. (2005). Linking objectively measured physical activity with objectively measured urban form: findings from SMARTRAQ. American Journal of Preventive Medicine, 28(2S2), 117-125.

Fredriks, A.M., Buuren, S., Van Hirasing, R.A., Wit, J.M. and Verloove-Vanhorick, S.P. (2005). Alarming prevalences of overweight and obesity for children of Turkish, Moroccan and Dutch origin in The Netherlands according to international standards. Acta Paediatrica, 94(4), 496-498.

Frumkin, H. (2002). Urban sprawl and public health. Public Health Reports, 117(3), 201-217.

Gomez, J.E. (2004). Violent crime and outdoor physical activity among inner-city youth. Preventive Medicine, 39, 876-881.

Gordon-Larsen, P., Nelson, M. C., Page, P. and Popkin, B.M. (2006). Inequality in the built environment underlies key health disparities in physical activity and obesity. Pediatrics, 117(2), 417-424.

Handy, S.L., Boarnet, M.G., Ewing, R. and Killingsworth, R. E. (2002). How the built environment affects physical activity. American Journal of Preventive Medicine, 23(2), 6473.

Haug, E., Torsheim, T., Sallis, J. F. and Samdal, O. (2010). The characteristics of the outdoor school environment associated with physical activity. Health Education Research, 25(2), 248-256.

Heelan, K. A., Donnelly, J. E., Jacobsen, D. J., Mayo, M. S., Washburn, R. and Greene, L. (2005). Active commuting to and from school and BMI in elementary school childrenpreliminary data. Child: Care, Health and Development, 31(3), 341-349.

Hind, K. and Burrows, M. (2007). Weight-bearing exercise and bone mineral accrual in children and adolescents: a review of controlled trials. Bone, 40(1), 14-27.

Hinkley, T., Crawford, D., Salmon, J., Okely, A.D. and Hesketh, K. (2008). Preschool children and physical activity: a review of correlates. American Journal of Preventive Medicine, 34(5), 435-441.

Holsten, J.E. (2009). Obesity and the community food environment: a systematic review. Public Health Nutrition, 12(3), 397-405. 
Hoppe, M.J., Wells, E.A., Morrison, D.M., Gillmore, M.R. and Wilsdon, A. (1995). Using focus groups to discuss sensitive topics with children. Evaluation Review, 19(1), 102-14.

Hume, C., Salmon, J. and Ball, K. (2005). Children's perceptions of their home and neighborhood environments, and their association with objectively measured physical activity: a qualitative and quantitative study. Health Education Research, 20 (1), 1-13.

Humpel, N., Owen, N. and Leslie, E. (2002). Environmental factors associated with adults' participation in physical activity: a review. American Journal of Preventive Medicine, 22(3), 188-199.

Iverson, D. C., Fielding, J. E., Crow, R. S. and Christenson, G. M. (1985). The promotion of physical activity in the United States population: the status of programs in medical, worksite, community, and school settings. Public Health Reports, 100(2), 212 - 214.

Janssen, I., Boyce, W. F., Simpson, K. and Pickett, W. (2006). Influence of individual- and area-level measures of socio-economic status on obesity, unhealthy eating, and physical inactivity in Canadian adolescents. American Journal of Clinical Nutrition, 83(1), 139-145.

Janz, K.F., Letuchy, E.M., Gilmore, J.M.E., Burns, T.L., Torner, J.C., Willing, M.C. and Levy, S.M. (2010). Early physical activity provides sustained bone health benefits later in childhood. Medicine and Science in Sports and Exercise, 42(6), 1072.

Kaczynski, A.T. and Henderson, K.A. (2007). Environmental correlates of physical activity: A review of evidence about parks and recreation. Leisure Sciences, 29(4), 315-354

Kaczynski, A.T., Potwarka, L.R. and Saelens, B.E. (2008). Association of park size, distance, and features with physical activity in neighborhood parks. American Journal of Public Health, 98(8), 1451-1456.

King, A.C., Parkinson, K.N., Adamson, A.J., Murray, L., Besson, H., Reilly, J.J. and Basterfield, L. (2011). Correlates of objectively measured physical activity and sedentary behavior in English children. European Journal of Public Health, 21(4), 424-431.

Klesges, L., Baranowski, T., Beech, B., Cullen, K.,Murray, D., Rochon, J. and Pratt, C. (2004). Social desirability bias in self-reported dietary, physical activity and weight concerns measures in 8 to 10-year old African-American girls: results from the Girls Health Enrichment Multisite Studies (GEMS). Preventive Medicine, 38(Supp), 78-87.

Koezuka, N., Koo, M., Allison, K.R., Adlaf, E.M., Dwyer, J.J., Faulkner, G. and Goodman, J. (2006). The relationship between sedentary activities and physical inactivity among adolescents: results from the Canadian Community Health Survey. Journal of Adolescent Health, 39(4), 515-522.

Krueger, R.A. and King, J.A. (1998). Involving Community Members in Focus Groups. SAGE: Thousand Oaks, CA.

Krueger, R.A. and Casey, M. (2000). Focus Groups: A Practical Guide for Applied Research. SAGE: Thousand Oaks, CA.

Lachowycz, K. and Jones, A.P. (2011). Greenspace and obesity: a systematic review of the evidence. Obesity Reviews, 12(5), 183-189.

Lackshman, R., McConville, A., How, S., Flowers, J., Wareham, N. and Cosford, P. (2010). Association between area-level socioeconomic deprivation and a cluster of behavioral risk factors: cross-sectional, population-based study. Journal of Public Health, 33(2), 234245. 
Lambert, E.V. and Goedecke, J.H. (2004). Energy balance and energy expenditure in obesityis obesity a disease of inactivity? South African Journal of Sports Medicine, 15(1), 21-25.

Lavin, T., Higgins, C., Metcalfe, O. and Jordan, A. (2006). Health effects of the built environment. Dublin, Institute of Public Health. Retrieved on December, 18, 2012. http://www.publichealth.ie/publications/healthimpactsofthebuiltenvironmentareview

Lee, A.C. and Maheswaran, R. (2010). The health benefits of urban green spaces: a review of the evidence. Journal of Public Health, 33(2), 212-222.

Lee, M.C., Orenstein, M.R. and Richardson, M.J. (2008). Systematic review of active commuting to school and children's physical activity and weight. Journal of Physical Activity and Health, 5(6), 930-949.

Lee, S.M. and Tudor-Locke, C. (2005). Active versus passive commuting to school: what children say. American Journal of Health Studies, 20(3/4), 212.

Leslie, A., Saelens, B., Frank, L., Owen, N., Baumand, A., Coffee, N. and Hugo, G. (2005). Residents' perceptions of walkability attributes in objectively different neighbourhoods: a pilot study. Health and Place, 11, 227-236.

Liu, G.G., Wilson, J.S., Qi, R. and Ying, R (2007). Green neighborhoods, food retail and childhood overweight: differences by population density. American Journal of Health Promotion, 21(4), 317-25.

Livingstone, M.B.E., Robson, P.J., Black, A.E., Coward, W.A., Wallace, J.M.W., McKinley, M. C. and McKenna, P.G. (2003). An evaluation of the sensitivity and specificity of energy expenditure measured by heart rate and the Goldberg cut-off for energy intake: basal metabolic rate for identifying mis-reporting of energy intake by adults and children: a retrospective analysis. European Journal of Clinical Nutrition, 57(3), 455-463.

Livingstone, M.B., Coward, W.A., Prentice, A.M., Davies, P.S., Strain, J.J., McKenna, P.G. and Kerr, M.J. (1992). Daily energy expenditure in free-living children: comparison of heart-rate monitoring with the doubly-labelled water (2H2 (18) O) method. The American Journal of Clinical Nutrition, 56(2), 343-352.

Lopez R.P. and Hynes, H.P. (2006). Obesity, physical activity and the urban environment: public health research needs. Environmental Health, 5(1), 25-35.

Loprinzi, P.D. and Cardinal, B.J. (2011). Measuring children's physical activity and sedentary behaviors. Journal of Exercise Science and Fitness, 9(1), 15-23.

Lorch, S.M. and Sharkey, A. (2007). Myocardial velocity, strain, and strain rate abnormalities in healthy obese children. Journal of Cardiometabolic Syndrome, 2(1),30-34.

Louie, L. and Chan, L. (2003). The use of pedometry to evaluate the physical activity levels among preschool children in Hong Kong. Early Child Development and Care, 173(1), 97107.

Maas, J., Verheij, R.A., de Vries, S., Spreeuwenberg, P., Schellevis, F.G. and Groenewegen, P.P. (2009). Morbidity is related to a green living environment. Journal of Epidemiology and Community Health, 63(12), 967-973.

Maddison, R. and Ni Mhurchu, C. (2009). Global positioning system: a new opportunity in physical activity measurement. International Journal of Behavioral Nutrition and Physical Activity, 6(1), 73. 
Maller, C., Townsend, M., Pryor, A., Brown, P. and St Leger, L. (2006). Healthy nature healthy people: 'contact with nature' as an upstream health promotion intervention for populations. Health Promotion International, 21(1), 45-54

Marshall, S.J., Levy, S.S., Tudor-Locke, C.E., Kolkhorst, F.W., Wooten, K.M., Ji, M., Macera, C.A. and Ainsworth, B.E. (2009). Translating physical activity recommendations into a pedometer-based step goal: 3000 steps in 30 minutes. American Journal of Preventive Medicine, 36(5), 410-415.

Matthews, H., Limb, M. and Taylor, M. (1998). The geography of children: some ethical and methodological considerations for project and dissertation work. Journal of Geography in Higher Education, 22(3), 311-324.

McGinn, A.P., Evenson, K.R., Herring, A.H., Huston, S.L. and Rodriguez, D.A. (2007). Exploring associations between physical activity and perceived and objective measures of the built environment. Journal of Urban Health, 84(2), 162-184.

McLeroy, K.R., Bibeau, D., Steckler, A. and Glanz, K. (1988). An ecological perspective on health promotion programs. Health Education Quarterly, 15(4), 351-377.

Mendoza, J.A., Watson, K., Nguyen, N., Cerin, E., Baranowski, T. and Nicklas, T.A. (2011). Active commuting to school and association with physical activity and adiposity among US youth. Journal of Physical Activity and Health, 8(4), 488-495.

Mitchell, R. and Popham, F. (2008). Effect of exposure to natural environment on health inequalities: an observational population study. Lancet, 372(9650), 1655-1660.

Mitchell, R., Astell-Burt, T. and Richardson, E.A. (2011). A comparison of green space indicators for epidemiological research. Journal of Epidemiology and Community Health, $10,1-6$.

Mitre, N., Lanningham-Foster, L., Foster, R. and Levine, J.A. (2009). Pedometer accuracy for children: can we recommend them for our obese population? Pediatrics, 123(1), 127-131.

Morgan, M., Gibbs, S., Maxwell, K. and Britten, N. (2002). Hearing children's voices: methodological issues in conducting focus groups with children aged 7-11 years. Qualitative Research, 2(1), 5-20.

Morrow, V. (2001). Using qualitative methods to elicit young people's perspectives on their environments: some ideas for community health initiatives. Health Education Research, 16(3), 255-268.

Mota, J., Silva, P., Santos, M.P., Ribeiro, J.C., Oliveira, J. and Duarte, J.A. (2005). Physical activity and school recess time: differences between the sexes and the relationship between children's playground physical activity and habitual physical activity. Journal of Sports Sciences, 23(3), $269-275$.

O'Dea, J.A. (2003). Why do kids eat healthful food? Perceived benefits of and barriers to healthful eating and physical activity among children and adolescents. Journal of the American Dietetic Association, 103(4), 497-501.

Oliver, M., Schofield, G.M., Grant, M. and Gregory, S. (2007). Physical activity in preschoolers: understanding prevalence and measurement issues. Sports Medicine, 37(12), 1045-1070.

Owen, N., Humpel, N., Leslie, E., Bauman, A. and Sallis, J.F. (2004). Understanding environmental influences on walking: review and research agenda. American Journal of Preventive Medicine, 27, 67-76. 
Owen, N., Leslie, E., Salmon, J. and Fotheringham, M.J. (2000). Environmental determinants of physical activity and sedentary behavior. Exercise and Sport Sciences Reviews, 28(4), 153-158.

Öner, N, Vatansever, Ü. and Sarı, A. (2004). Prevalence of underweight, overweight and obesity in Turkish adolescents. Swiss Medical Weekly, 134, 529-533.

Özdemir, A. (2010). The Authentic Landscape Design of Primary School's Yards. Ankara University Scientific Research Projects Unit, Final Report for the Project No: 09 Ö4347001.

Özdemir, A. and Yilmaz, O. (2008). Assessment of outdoor school environments and physical activity in Ankara's primary schools. Journal of Environmental Psychology, 28(3), 287-300.

Özdemir, A. and Çorakçı, M. (2010). Participation in the greening of schoolyards in the Ankara public school system. Scientific Research and Essays, 5(15), 2065-2077.

Pabayo, R., Gauvin, L. and Barnett, T.A. (2011). Longitudinal changes in active transportation to school in Canadian youth aged 6 through 16 years. Pediatrics, 128(2), 404-413.

Papas, M.A., Alberg, A.J., Ewing, R., Helzlsouer, K.J., Gary, T.L. and Klassen, A.C. (2007). The built environment and obesity. Epidemiologic Reviews, 29(1), 129-143.

Pate, R.R., Pratt, M., Blair, S.N., Haskell, W.L., Macera, C.A., Bouchard, C., et al. (1995). Physical activity and public health. A recommendation from the Centers for Disease Control and Prevention and the American College of Sports Medicine. Journal of the American Medical Association, 273(5), 402-407.

Pate, R.R., O'Neill, J.R., and Lobelo, F. (2008). The evolving definition of 'sedentary'. Exercises and Sport Sciences Reviews, 36(4), 173-178.

Pate, R.R., O'Neill, J.R. and Mitchell, J. (2010). Measurement of physical activity in preschool children. Medicine and Science in Sports and Exercise, 42(3), 508-512.

Pikora, T., Giles-Corti, B., Bull, F., Jamrozik, K. and Donovan, R. (2003). Developing a framework for assessment of the environmental determinants of walking and cycling. Social Science and Medicine, 56(8), 1693-1704.

Potwarka, L.R., Kaczynski, A.T. and Flack, A.L. (2008). Places to play: association of park space and facilities with healthy weight status among children. Journal of Community Health, 33(5), 344-350.

Raitakari, O. T., Taimela, S., Porkka, K. V., Telama, R., Valimaki, I., Akerblom, H. K. and Viikari, J. S. (1997). Association between physical activity and risk factors for coronary heart disease: The Cardiovascular Risk in Young Finns Study. Medicine and Science in Sports and Exercise, 29(8), 1055-1061.

Richardson, E.A. and Mitchell, R. (2010). Gender differences in relationships between urban green space and health in the United Kingdom. Social Science and Medicine, 71(3), 568575.

Ridgers, N.D., Stratton, G., Fairclough, S.J. and Twisk, T.W. (2007). Long-term effects of playground markings and physical structures on children's recess physical activity levels. Preventive Medicine, 44(5), 393-397. 
Ridgers, N.D., Stratton, G., Clark, E., Fairclough, S.J. and Richardson, D.J. (2006). Day-to-day and seasonal variability of physical activity during school recess. Preventive Medicine, 42(5), 372-374.

Ridgers, N.D., Stratton, G. and Fairclough, S.J. (2006). Physical activity levels of children during school playtime. Sports Medicine, 36(4), 359-371.

Rivkin, M. (1997). The schoolyard habitat movement: What it is and why children need it. Early Childhood Education, 25(1), 61-66.

Roemmich, J.N., Epstein, L.H., Raja, S., Yin, L., Robinson, J. and Winiewicz, D. (2006). Association of access to parks and recreational facilities with the physical activity of young children. Preventive Medicine, 43(6), 437-441.

Rosenberg, D.E., Sallis, J.F., Conway, T.L., Cain, K.L. and McKenzie, T.L. (2006). Active transportation to school over 2 years in relation to weight status and physical activity. Obesity, 14(10), 1771-1776.

Rowland, T.W. (1990). Exercise and Children's Health. Champaign, IL: Human Kinetics.

Rowlands, A.V. and Eston, R.G. (2007). The measurement and interpretation of children's physical activity. Journal of Sports Science and Exercise, 6, 270-276.

Rowlands, A.V., Eston, R.G. and Ingledew, D.K. (1997). Measurement of physical activity in children with particular reference to the use of heart rate and pedometry. Sports Medicine, 24, 258-272.

Saegert, S. (1982). Environments and children's mental health: residential density and low income children. In: A. Baum and J.E. Singer (Eds.), Handbook of Psychology and Health (pp. 247-271). Hillsdale, NJ: Erlbaum.

Saelens, B.E., Sallis, J.F., Black, J.B. and Chen, D. (2003). Neighborhood-based differences in physical activity: an environment scale evaluation. American Journal of Public Health, 93(9), 1552-1558.

Saelens, B.E., Sallis, J.F. and Frank, L.D. (2003). Environmental correlates of walking and cycling: findings from the transportation, urban design, and planning literatures. Annals of Behavioral Medicine, 25(2), 80-91.

Sallis, J.F., Hovell, M.F., Hofstetter, C.R., Elder, J.P., Hackley, M., Caspersen, C.J. and Powell, K.E. (1990). Distance between homes and exercise facilities related to the frequency of exercise among San Diego residents. Public Health Reports, 105(2), 179-185.

Sallis, J.F., Nader, P., Broyles, S., Berry, C., Elder, J., McKenzie, T. and Nelson, J. (1993). Correlates of physical activity at home in Mexican-American and Anglo-American preschool children. Health Psychology, 12(5), 390-400.

Sallis, J.F. and Owen, N. (1997). Ecological models. In: K. Glanz, F.M. Lewis and B.K. Rimer (Eds.), Health Behavior and Health Education: Theory, Research and Practice (pp.403-424). San Francisco: Jossey-Bass.

Sallis, J.F., Bauman, A. and Pratt, M. (1998). Environmental and policy interventions to promote physical activity. American Journal of Preventive Medicine, 15(4), 379-397.

Sallis, J.F. and Owen, N. (1999). Physical Activity and Behavioral Medicine. Thousand Oaks, CA: Sage Publications.

Sallis, J.F., Judith P. and Wendell, T. (2000). A review of correlates of physical activity of children and adolescents. Medicine and Science in Sports and Exercise, 32(5), 963-75. 
Sallis, J.F., Conway, T.L., Prochaska, J.J., McKenzie, T.L., Marshall, S.J. and Brown, M. (2001). The association of school environments with youth physical activity. American Journal of Public Health, 91(4), 618.

Sallis, J.F., McKenzie, T.L., Conway, T.L., Elder, J.P., Prochaska, J.J., Brown, M., et al. (2003). Environmental interventions for eating and physical activity - a randomized controlled trial in middle schools. American Journal of Preventive Medicine, 24(3), 209-217.

Sallis, J.F., Saelens, B.E., Frank, L.D., Conway, T.L., Slymen, D.J., Cain, K.L., et al. (2009). Neighborhood built environment and income: examining multiple health outcomes. Social Science and Medicine, 68(7), 1285-1293.

Sallis, J.F., Taylor, W.C., Dowda, M., Freedson, P.S. and Pate, R.R. (2002). Correlates of vigorous physical activity for children in grades 1 through 12: comparing parentreported and objectively measured physical activity. Pediatric Exercise Science, 14(1), 3044.

Sallis, J.F., Kraft, K., Cutter, C.L., Kerr, J., Weitzel, J. and Wilson, A. (2009). The active living research program. American Journal of Preventive Medicine, 36(2), 10-21.

Sharples, M., Davison, L., Thomas, G. and Rudman, P. (2003). Children as photographers: an analysis of children's photographic behavior and intentions at three age levels. Visual Communication, 2(3), 303-30.

Shaw, M. (2004). Housing and public health. Annual Review of Public Health, 25, 397-418.

Shultz, S.P., Browning, R.C., Schutz, Y., Maffeis, C. and Hills, A.P. (2011). Childhood obesity and walking: guidelines and challenges. International Journal of Pediatric Obesity, 6(5-6), 332-341.

Singh, A., Uijtdewilligen, L., Twisk, J.W., Van Mechelen, W. and Chinapaw, M.J. (2012). Physical activity and performance at school: a systematic review of the literature including a methodological quality assessment. Archives of Pediatrics and Adolescent Medicine, 166(1), 49-55.

Sirard, J. and Pate, R. (2001). Physical activity assessment in children and adolescents. Sports Medicine, 31(6), 439-454.

Spurr, G.B., Prentice, A.M., Murgatroyd, P.R., Goldberg, G.R., Reina, J.C. and Christman, N.T. (1988). Energy expenditure from minute-by-minute heart-rate recording: comparison with indirect calorimetry. American Journal of Clinical Nutrition, 48(3), 552559.

Stice, E., Shaw, H. and Marti, C.N. (2006). A meta-analytic review of obesity prevention programs for children and adolescents: the skinny on interventions that work. Psychological Bulletin, 132(5), 667-691.

Stigsdotter, U.K., Ekholm, O., Schipperijn, J., Toftager, M., Kamper-Jørgensen, F. and Randrup, T.B. (2010). Health promoting outdoor environments: associations between green space, and health, health-related quality of life and stress based on a Danish national representative survey. Scandinavian Journal of Public Health, 38(4), 411-417.

Story, M., Kaphingst, K.M. and French, S. (2006). The role of schools in obesity prevention. Future of Children, 16(1), 109-142.

Stratton, G. and Mullan, E. (2005). The effect of multicolor playground markings on children's physical activity level during recess. Preventive Medicine, 41, 828-833. 
Strong, W.B., Malina, R.M., Blimkie, C.J., Daniels, S.R., Dishman, R.K., Gutin, B., Hergenroeder, A.C., Must, A., Nixon, P.A., Pivarnik, J.M. et al (2005). Evidence based physical activity for school-age youth. Journal of Pediatrics, 146(6), 732-737.

Strong, K.A., Parks, S.L., Anderson, E., Winett, R. and Davy, B.M. (2008). Weight gain prevention: identifying theory-based targets for health behavior change in young adults. Journal of the American Dietetic Association, 108(10), 1708-1715.

Stucky-Ropp, R. and DiLorenzo, T.M. (1993). Determinants of exercise in children. Preventive Medicine, 22(6), 880-889.

Sugiyama, T., Leslie, E., Giles-Corti, B. and Owen, N. (2008). Associations of neighborhood greenness with physical and mental health: do walking, social coherence and local social interaction explain the relationships? Journal of Epidemiology and Community Health, 62(5), e9.

Şimşek, F., Ulukol, B., Berberoğlu, M. and Gülnar, S.B. (2005). Ankara'da bir ilköğretim okulu ve lisede obezite sıklığı. Ankara Üniversitesi Tıp Fakültesi Dergisi, 58, 163-166.

Takano, T., Nakamura, K. and Watanabe, M. (2002). Urban residential environments and senior citizens' longevity in megacity areas: the importance of walkable green spaces. Journal of Epidemiology and Community Health, 56(12), 913-918.

Teixeira, P.J., Sardinha, L.B., Going, S.B. and Lohman, T.G. (2001). Total and regional fat and serum cardiovascular disease risk factors in lean and obese children and adolescents. Obesity Research, 9(8), $432-442$.

Tranter, P.J. and Malone, K. (2004). Geographies of environmental learning: an exploration of children's use of school grounds. Children's Geographies, 2(1), 131-155.

Trudeau, F. and Shepherd, R.J. (2005). Contribution of school programs to physical activity levels and attitudes in children and adults. Sports Medicine, 35(2), 89-105.

Trost, S.G., Pate, R.R., Freedson, P.S., Sallis, J.F. and Taylor, W.C. (2000). Using objective physical activity measures with youth: how many days of monitoring are needed? Medicine and Science in Sports and Exercise, 32(2), 426-431.

Trost, S.G., Kerr, L.M., Ward, D.S. and Pate, R.R. (2001). Physical activity and determinates of physical activity in obese and non-obese children. International Journal of Obesity, 25(6), 822-829.

Trost, S.G., Owen, N., Bauman, A.E., Sallis, J.F. and Brown, W. (2002). Correlates of adults' participation in physical activity: review and update. Medicine and Science in Sports and Exercise, 34(12), 1996-2001.

Tudor-Locke, C.E. and Bassett, D.R. (2004). How many steps are enough? Pedometerdetermined physical activity indices. Sports Medicine, 34(1), 1-8.

Tudor-Locke, C., Craig, C.L., Beets, M.W., Belton, S., Cardon, G.M., Duncan, S., Hatano, Y., Lubans, D.R., Olds, T.S., Raustorp, A. et al. (2011). How many steps/day are enough? for children and adolescents. International Journal of Behavioral Nutrition and Physical Activity, 8(1), 78.

Uğuz, M. and Bodur, S. (2007). Konya il merkezindeki ergenlik öncesi ve ergen çocuklarda aşırı ağırlık ve şişmanlık durumunun demografik özelliklerle ilişkisi. Genel Tıp Dergisi, 17(1), 1-7. 
Uluocak, N., Parlaktaş, B.S., Erdemir, F. and Çağlar, M.N. (2006). Sağlıklı okul çağı çocukalrında böbrek boyutlarının vücut kitle indeksi ve cinsiyet ile olan ilişkisi. Çocuk Ürolojisi, 32(3), 370-374.

Van Emmerik, N.M., Renders, C.M., van deVeer, M., van Buuren, S., van der Baan-Slootweg, O.H., Kist-van Holthe, J.E. and Hirasing, R.A. (2012). High cardiovascular risk in severely obese young children and adolescents. Archives of Disease in Childhood, 97(9), 818-821.

Van Lenthe, F., Brug, J. and Mackenbach, J. (2005). Neighborhood inequalities in physical inactivity: the role of neighborhood attractiveness, proximity to local facilities and safety in the Netherlands. Social Science and Medicine, 60(4), 763-775.

Van Mechelen, W., Twisk, J.W., Post, G.B., Snel, J.A.N. and Kemper, H.C. (2000). Physical activity of young people: The Amsterdam Longitudinal Growth and Health Study. Medicine and Science in Sports and Exercise, 32(9), 1610-1616.

Van Sluijs, E.M., Jones, N.R., Jones, A.P., Sharp, S.J., Harrison, F. and Griffin, S.J. (2012). School-level correlates of physical activity intensity in 10-year-old children. International Journal of Pediatric Obesity, 6(2Part2), 574-581.

Vaughn, S., Schumm, J.S. and Sinagub, J. (1996). Use of focus groups with children and adolescents. In: J.M. Sinagub, S. Vaughn and J.S. Schumm (Eds.), Focus Group Interviews in Education and Psychology (pp. 128-142). Thousand Oaks, CA: Sage.

Verstraete, S.J., Cardon, G.M., De Clercq, D.L.R. and De Bourdeaudhuij, I.M.M. (2006). Increasing children's physical activity levels during recess periods in elementary schools: the effects of providing game equipment. European Journal of Public Health, 16(4), 415-419.

Veugelers, P.J., Sithole, F., Zhang, S. and Muhajarine, N. (2008). Neighborhood characteristics in relation to diet, physical activity and overweight of Canadian children. International Journal of Pediatric Obesity, 3(3), 152-159.

Veugelers, P.J. and Fitzgerald, A.L. (2005). Prevalence of and risk factors for childhood overweight and obesity. Canadian Medical Association Journal, 173(6), 607-613.

Vincent, S.D. and Pangrazi, R.P. (2002). An examination of the activity patterns of elementary school children. Pediatric Exercise Science, 14(4), 432-441.

Vita, P. and Owen, N. (1995). A perspective on the behavioral epidemiology: the determinants and the stages of exercise involvement. Australian Psychologist, 30(2), 135140.

Wabitsch, M. (2000). Overweight and obesity in European children and adolescents: causes and consequences, treatment and prevention: an introduction. European Journal of Pediatrics, 159(3), 8-13.

Wang, C. and Burris, M.A. (1997). Photovoice: concept, methodology, and use for participatory needs assessment. Health Education and Behavior, 24(3), 369-387.

Weick, K.E. and Quinn, R.E. (1999). Organizational change and development. Annual Review of Psychology, 50(1), 361-386.

Weinsier, R.L., Hunter, G.R., Heini, A.F., Goran, M.I. and Sell, S.M. (1998). The etiology of obesity: relative contribution of metabolic factors, diet, and physical activity. American Journal of Medicine, 105(2), 145-150. 
Wechsler, H., Devereaux, A.B., Davis, M. and Collins, J. (2000). Using the school environment to promote physical activity and healthy eating. Preventive Medicine, 31(2), 121-137.

Welk, G.J. (2002). Physical Activity Assessments for Health-Related Research. Champaign, IL: Human Kinetics Publishers.

Welk, G.J., Corbin, C.B. and Dale, D. (2000). Measurement issues in the assessment of physical activity in children. Research Quarterly for Exercise and Sport, 71, 59-73.

Wells, N.M. and Evans, G.W. (2003). Nearby Nature: A Buffer of Life Stress among Rural Children. Environment and Behavior, 35(3), 311-330

Wells, N.M. and Yang, Y. (2008). Neighborhood design and walking: a quasi-experimental longitudinal study, American Journal of Preventive Medicine, 34(4), 313-318.

Wendel-Vos, W., Droomers, M., Kremers, S., Brug, J. and Van Lenthe, F. (2007). Potential environmental determinants of physical activity in adults: a systematic review. Obesity reviews, 8(5), 425-440.

Wendel-Vos, G.C., Schuit, A.J., de Niet, R., Boshuizen, H.C., Saris, W.H. and Kromhout, D. (2004). Factors of the physical environment associated with walking and bicycling. Medicine and Science in Sports and Exercise, 36, 725-730.

Wheeler, B.W., Cooper, A.R., Page, A.S. and Jago, R. (2010). Greenspace and children's physical activity: A GPS/GIS analysis of the PEACH project. Preventive Medicine, 51(2), 148-152.

Whitehouse, S., Varni, J.W., Seid, M., Cooper-Marcus, C., Ensberg, M.J., Jacobs, J.R. and Mehlenbeck, R.S. (2001). Evaluating a children's hospital garden environment: utilisation and consumer satisfaction. Journal of Environmental Psychology, 21, 301-314.

Whitt, M.C., DuBose, K.D., Ainsworth, B.E. and Tudor-Locke, C. (2004). Walking patterns in a sample of African American, Native American, and Caucasian women: the crosscultural activity participation study. Health Education and Behavior, 31(Suppl 4), 45-56.

Wigle, D.T. (2003). Child Health and the Environment. New York: Oxford University Press.

Young, L. and Barrett, H. (2001). Adapting visual methods: action research with Kampala street children. Area, 33(2), 141-52.

Zask, A., Van Beurden, E., Barnett, L.M., Brooks, L.O. and Dietrich, U.C. (2001). Active school playgrounds-myth or reality? Results of the 'Move It Groove It' project. Preventive Medicine, 33(5), 402-408.

Zimring, C., Joseph, A., Nicoll, G. L. and Tsepas, S. (2005). Influences of building design and site design on physical activity: research and intervention opportunities. American Journal of Preventive Medicine, 28(2), 186-193. 